\title{
Do Fiscal Rules Matter?
}

\author{
By Veronica Grembi, Tommaso Nannicini, and Ugo Troiano*
}

Fiscal rules are laws aimed at reducing the incentive to accumulate debt, and many countries adopt them to discipline local governments. Yet, their effectiveness is disputed because of commitment and enforcement problems. We study their impact applying a quasi-experimental design in Italy. In 1999, the central government imposed fiscal rules on municipal governments, and in 2001 relaxed them below 5,000 inhabitants. We exploit the before/after and discontinuous policy variation, and show that relaxing fiscal rules increases deficits and lowers taxes. The effect is larger if the mayor can be reelected, the number of parties is higher, and voters are older. (JEL E62, H71, H72, H74, R51)

F iscal rules are laws designed to constrain fiscal policy. Many countries have adopted fiscal rules to discipline local governments, including Argentina, Austria, Brazil, Canada, China, Colombia, Czech Republic, Denmark, Italy, Mexico, Poland, Spain, Sweden, and Turkey. In all of the above mentioned countries, fiscal rules are imposed by the national government on local governments. ${ }^{1}$ Despite their wide diffusion, there is no consensus about whether fiscal restraints matter for increasing fiscal stability. A number of studies have argued that there are several reasons why fiscal rules might be ineffective in restraining fiscal policy (see the

\footnotetext{
* Grembi: Copenhagen Business School, Solbjerb Plads 3, 2000 Frederiksberg, Denmark (e-mail: vg.jur@cbs. dk); Nannicini: Economics Department, Bocconi University, Via Roentgen, 20136 Milan, Italy, IGIER, CEPR, and IZA (e-mail: tommaso.nannicini@unibocconi.it); Troiano: Department of Economics, University of Michigan, 611 Tappan Avenue, 219 Lorch Hall, Ann Arbor, MI 48109 and NBER (e-mail: troiano@ umich.edu). A previous version of this paper circulated under the title "Policy Responses to Fiscal Restraints: A Difference-in-Discontinuities Design.” We thank Alberto Alesina, Robert Barro, Raj Chetty, Larry Katz, three anonymous referees, Philippe Aghion, Roland Benabou, David Cutler, John Friedman, Ed Glaeser, Josh Hausman, Nathan Hendren, Brian Knight, David Laibson, Amanda Pallais, Per Pettersson-Lidbom, László Sándor, Frank Schilbach, and seminar participants at Bank of Italy, Bologna University, Boston University, CELS 2012 Northwestern University, CEPR Public Policy Symposium 2012, Catholic University of Milan, CIFAR, CeSiFo, CREI, CSEF Naples, Erasmus University Rotterdam, Harvard Development, Labor and Macro Lunch, IGIER-Bocconi, IIES, NBER SI 2012, UCSD, University of Michigan, and USI Lugano, for their insightful comments. Errors are ours and follow a random walk. Financial support is gratefully acknowledged from Catholic University of Milan for Grembi; the ERC (Grant No. 230088) and Bocconi University for Nannicini; Harvard Department of Economics and Multidisciplinary Program in Inequality and Social Policy, Bank of Italy, and Bradley for Troiano. We also thank Giancarlo Verde, Carmine La Vita, Daniela De Marte (Italian Ministry of the Interior), and Salvatore Parlato (Ifel-ANCI) for help with data collection.

Go to http://dx.doi.org/10.1257/app.20150076 to visit the article page for additional materials and author disclosure statement(s) or to comment in the online discussion forum.

${ }^{1}$ Although in a few countries fiscal rules are self-imposed by fiscal authorities, it should be noted that one of the most cited examples of fiscal rules, the European Stability Pact, is also not self-imposed, but imposed by the European Union on the member countries.
} 
reviews by Alesina and Perotti 1996, and Wyplosz 2012), for instance because of commitment or enforcement problems. ${ }^{2}$

Studying whether fiscal rules matter for policies is challenging. The search for a definitive conclusion about how fiscal rules affect fiscal policy has been hampered by the potentially endogenous decision of whether to adopt a fiscal rule in the first place (Poterba 1996 or Alesina and Perotti 1996). ${ }^{3}$ In this paper, we study the effect of relaxing fiscal restraints at the local government level. We first show quasi-experimentally that fiscal rules do matter for restraining the accumulation of debt and that fiscal adjustment seems to be concentrated on revenues. We then give evidence suggesting that the adjustment is driven by cities with more political distortions.

Our testing ground is Italy, where the central government set a target on deficit reduction for all municipal governments in 1999-the so called "Domestic Stability Pact," henceforth, DSP - and relaxed it for municipalities below 5,000 inhabitants in 2001. The main rule established by the DSP imposed a gradual reduction of the "fiscal gap," defined as the municipal deficit net of transfers and debt service. ${ }^{4}$ In the regulatory environment we study, there is a central authority that can collect standardized public accounts and enforce punishment for noncompliers. Yet, the approval of the DSP was accompanied by widespread skepticism about its effectiveness, because Italy usually ranks last among OECD countries in ratings of law enforcement and government effectiveness (e.g., see Kaufmann, Kraay, and Mastruzzi 2010). In other words, our results suggest that the lessons we draw from Italian cities on the effectiveness of fiscal restraints may extend to other regulatory environments where the fiscal authority setting the rules faces critical ex ante commitment problems.

To study the effects of relaxing the fiscal rules, we cannot adopt a regression discontinuity design because there is another policy, the salary of the mayor, that changes sharply at the threshold of 5,000 inhabitants. We cannot apply a difference-in-differences design because large and small municipalities are typically on differential trends in public policies. ${ }^{5}$ Therefore, we combine two sources of

\footnotetext{
${ }^{2}$ The fact that subnational policymakers have limited discretion in changing fiscal policy is the central reason for which fiscal rules on local governments might not work. Furthermore, most fiscal rules, including those we study, are not embedded in the Constitution. This implies that fiscal responsibility laws can be frequently changed and revised, and they might suffer from the same time inconsistency problem that characterizes fiscal policy. Additionally, Alesina and Perotti (1996) argue that lax enforcement is one of the reasons why fiscal rules might not work. This concern, however, is more relevant at the national level, since at the local level the central government can be a credible enforcement authority. Finally, rules usually target only some parts of the budget and this offers opportunities for policymakers to sidestep the rules by complying with them without changing the overall fiscal discipline—see Milesi-Ferretti (2004).

${ }^{3}$ As indicated by Drazen (2002) in a review article: "A key question (perhaps the key question) about fiscal rules is whether they have the effect of slowing the growth of deficits." Furthermore, there has been limited investigation on fiscal rules at the local government level, where forms of "hidden" public debt can grow and raise fears about the overall financial sustainability of a country. For a review of the current state of the literature, see Glaeser (2013).

${ }^{4}$ The rationale for the exemption of municipalities with less than 5,000 inhabitants in 2001 was to avoid burdening very small towns with onerous requirements, as they may be disadvantaged by economies of scale in managing the municipal government. The penalties put in place for not complying with the DSP included a cut in the annual transfers from the central government, a ban on new hires, and a cut on reimbursement and non-absenteeism bonuses.

${ }^{5}$ We verify in online Appendix Figure A1 that the assumption of parallel trends does not hold in a standard difference-in-differences design.
} 
variation, before/after 2001 and just below/above 5,000 inhabitants, and implement what we called a "difference-in-discontinuities" (or diff-in-disc) design: taking the difference between the pretreatment and the posttreatment discontinuity at 5,000 inhabitants, in order to difference out the effect of the salary of the mayor. We propose and verify a set of diagnostic tests for this design.

We divide our empirical analysis into three parts. First, we analyze the effects of relaxing fiscal restraints on the deficit, which is the main policy variable of interest, and on the fiscal gap, which is the main target of the law. We find that relaxing fiscal rules translates into a larger fiscal gap of about 30 percent over the course of the following four years. This large effect on the main target of the DSP has real consequences for policy outcomes, as unconstrained municipalities increase their deficit by about 20 euros per capita ( 2 percent of the total budget). The magnitude of this effect appears to be sensitive to the bandwidth we consider, but the sign and statistical significance of the effect is robust.

In the second part of our empirical analysis, we study the composition of the fiscal adjustment, by analyzing municipal financial reports and administrative data on municipal tax rates, which are set by the local policymakers. We find that municipalities for which the rule is relaxed have statistically similar expenditure levels compared to constrained ones, although the standard errors are large, also because of the presence of outliers. Additionally, we find that unconstrained municipalities have lower tax revenues. This difference can be partially explained by the additional finding that municipalities for which fiscal rules are relaxed set lower tax rates. The main tax rates decided by Italian cities are a real estate tax rate on home property (Imposta Comunale sugli Immobili, ICI), which provides almost 50 percent of municipal tax revenues, and a surcharge on the personal income tax (Imposta sul Reddito delle Persone Fisiche, IRPEF), which amounts for about 10 percent of municipal tax revenues. Cities for which fiscal rules are relaxed have both a lower real estate tax rate (by about 14 percent) and a lower income tax surcharge (by about 30 percent) after the policy shift. The fact that we find an effect not only for the target of the DSP, but also both for the main policy variable of interest not targeted by the law (deficit) and for tax rates, alleviates concerns arising from the possibility of creative accounting.

Finally, in the third part of the analysis, we exploit the fact that our setup - that is, an exogenously imposed fiscal destabilization - can provide new evidence on when fiscal restraints matter the most. On the one hand, the optimal tax smoothing theory would suggest that the main cost of imposing fiscal rules is restricting countercyclical deficits. ${ }^{6}$ On the other hand, fiscal restraints might increase welfare if deficit is the suboptimal result of the interplay between rational politicians, voters, and interest groups.

We first study if the relaxation of fiscal rules is affected by whether the mayor faces a binding term limit or not. We find that the increase in deficit arises only for mayors who can be reelected. This result is consistent with models linking deficits to reelection incentives (Aghion and Bolton 1990) or to politicians' pandering to voters (Maskin and Tirole 2004). 
We then see whether municipalities with a different number of political parties represented in the local legislative assembly reacted differently to the relaxation of the restraints. Our results show that the higher the number of parties, the more the deficit increased after the relaxation of the restraint. This finding may be consistent with models that explain fiscal instability as the result of political fragmentation and of dynamic common pool (Persson and Tabellini 2000), although this is one among the many potential interpretations and our setting does not allow us to discriminate among the different models of the effects of political parties on deficit, or even to rule out alternative hypotheses (e.g., see Pettersson-Lidbom 2012). We also show that cities that increase the municipal deficit after the relaxation of fiscal rules have an older population. These results may be consistent with the model of Song, Storesletten, and Zilibotti (2012), according to which young citizens have a disciplining role for fiscal policy because they internalize the future costs of present fiscal instability. Finally, we show that the increase in deficit arises only for mayors who are slower in providing public goods.7]

Our results survive a large number of robustness checks. Among those, we use the introduction of the DSP for all municipalities in 1999 as a falsification test to show that our results are not driven by cities just below and just above 5,000 responding differently to the same set of fiscal rules. This test suggests that better paid (and, hence, better selected) mayors do not react differently to the introduction of the DSP compared to the other mayors. This is also reassuring for the external validity of our results. Additionally, we repeat this falsification exercise by interacting our treatment variable with the heterogeneity dimensions discussed above, in order to show that the law did not bind differently across those subsamples. We also show that there is no difference in manipulative sorting around 5,000 between the pretreatment and the posttreatment period, and — last but not least—-that municipalities just below and just above the threshold were on parallel trends in the pretreatment period.

This paper relates to two strands of literature. First, we contribute to the literature that has analyzed the effectiveness of fiscal rules. ${ }^{8}$ Previous evidence primarily comes from cross-country comparisons in specific regions, such as the European Union (see Hallerberg and Von Hagen 1999; Debrun et al. 2008) or Latin America (see Gavin and Perotti 1997), and from local governments in a federal state, such

\footnotetext{
${ }^{7}$ Our results suggest that fiscal restraints on subnational governments may have the positive welfare benefits mentioned above because they may bind more on municipalities characterized by higher political distortions, and limited welfare costs and because the tools for countercyclical fiscal policy are often administered at the country level (as discussed by Gavin and Perotti 1997 and Hines, Gale, and Knight 2010). Thus, our heterogeneous treatment effects can offer a suggestive explanation for the empirical fact that fiscal rules are much more likely to be observed for local rather than national governments around the world, as documented by Glaeser (2013). However, the nature of our evidence does not allow us to draw definite conclusions about the welfare effects of the intervention.

${ }^{8}$ For surveys, see Poterba and Von Hagen (1999) and Wyplosz (2012). For an extensive review on the types of rules and the main empirical evaluations of their impact, see IMF (2009). Balassone, Franco, and Zotteri (2004) review the literature on subnational fiscal rules in the European Union. As we focus on local governments, our results are particularly relevant for the literature that has emphasized that the implementation of subnational fiscal rules faces serious commitment problems, in the form of future overhaul, soft budget constraints, and lack of enforcement: see, among others, Eichengreen and von Hagen (1996); Braun and Tommasi (2004); Sutherland, Price, and Joumard (2005); and Ter-Minassian (2007). Feld and Kirchgäessner (2008) discuss the effects of the Swiss debt brakes, a type of fiscal rule, on cantons' fiscal discipline.
} 
as the United States (see Poterba 1994; 1996). 9 While some studies find that fiscal rules do indeed result in lower budget imbalances, others stress the reasons why they might not be effective (see Alesina and Perotti 1999). We contribute to this literature by analyzing the effectiveness of fiscal restraints with a quasi-experimental design where we control for omitted factors that may affect previous results, such as the fact that more disciplined constituencies introduce tighter rules, or that (current and past) legal institutions are endogenous to cultural values. ${ }^{10}$

Secondly, we contribute to the large literature on the political economy of deficit determination, as we identify a set of politicians' and voters' characteristics associated with a larger deficit response when the rules are relaxed. ${ }^{11}$ From a normative perspective, the optimality of fiscal rules is not obvious. Fiscal rules are not optimal in a frictionless world, but they might become optimal when deficits are the suboptimal result of the interplay between rational politicians, voters, and interest groups. ${ }^{12}$

The paper proceeds as follows. Section I describes the Italian institutions. Section II lays out our identification strategy. Section III describes the data. Section IV discusses the empirical results. We conclude with Section V.

\section{Institutional Framework}

Fiscal rules can be applied either by national governments or by local governments. Both national and subnational rules can be either self-imposed or imposed by an external authority. For instance, the European Stability Pact is imposed by the European Union to the members states. The fiscal rules imposed on US states are instead self-imposed. There are three ways through which laws can achieve fiscal discipline: (i) delegation to an agent; (ii) binding numerical rules; and (iii) improving budgetary process (Wyplosz 2012). It appears that our results are more likely to generalize for numerical fiscal rules that are imposed by a national government on municipalities.

The Italian municipal government (Comune) is composed of a mayor (Sindaco), an executive committee (Giunta) appointed by the mayor, and an elected city council (Consiglio Comunale) that must endorse the annual budget proposed by the mayor. The mayor and the executive committee-whose members can be dismissed by the mayor at will—propose changes in fiscal policy, such as adjustments in the tax rates. Subsequently, the city council votes on the proposed changes. Since 1993, mayors have been directly elected (with single round plurality rule in cities below 15,000 inhabitants) and face a two-term limit. Municipalities manage about

\footnotetext{
${ }^{9}$ Studies on the United States also include Von Hagen (1991), Alt and Lowry (1994), Bayoumi and Eichengreen (1995), Bohn and Inman (1996), Alesina and Bayoumi (1996), Knight (2000), Auerbach (2006), Clemens (2012), and Clemens and Miran (2012).

${ }^{10}$ On the endogenous determination of laws, see Aghion, Alesina, and Trebbi (2004) and Givati and Troiano (2012). From a theoretical perspective, other authors analyze the welfare effect of fiscal restraints: Besley and Smart (2007) study limits on the size of government in a two-period agency model; Bassetto and Sargent (2006) study the welfare case for allowing the government to issue debt only to finance certain expenditures.

${ }^{11}$ This literature has been reviewed by Alesina and Perotti (1999).

${ }^{12}$ This is consistent with the aforementioned Alesina and Tabellini (1990); Persson and Svensson (1989); Aghion and Bolton (1990); Besley (2007); Battaglini and Coate (2008); and Song, Soresletten, and Zilibotti (2012). Other political economy models on deficit determination include Tabellini and Alesina (1990); Lizzeri (1999); Besley (2007); Azzimonti, Battaglini, and Coate (2010); and Yared (2010).
} 
10 percent of total public expenditure and are in charge of a wide range of services, including water supply, waste management, municipal police, infrastructures, welfare, and housing. Only about 20 percent of revenues are local revenues.

After the European Union adopted its Stability and Growth Pact in 1997, some European countries - including Italy — adopted subnational fiscal rules to keep local governments accountable. In December 1998, the Italian annual budget law (Legge Finanziaria) for 1999 introduced a set of rules that constrained all municipalities in terms of fiscal discipline, the aforementioned Domestic Stability Pact or DSP (Patto di Stabilità Interno). 13

Municipal governments were constrained to keep the growth of their fiscal gapdefined as deficit, net of transfers, and debt service- under tight control. The rationale for the exclusion of debt service and transfers in the definition of the DSP target is twofold. First, mayors are not held accountable for expenses on interest (which depend on previously contracted loans) and for revenues from transfers (which are not raised by the municipality). Second, these two items are the tools that the central government uses to enforce fiscal rules, reducing interest payments for compliers and cutting transfers for noncompliers. The punishment established for not complying with the DSP included the following penalties: (i) 5 percent cut in the annual transfers from the central government; (ii) ban on municipal hires; and (iii) 30 percent cut on reimbursement and non-absenteeism bonuses for the employees of the municipal administration. Cities complying with the DSP, instead, benefited from a reduction of the expenses on interests for loans from the central government. ${ }^{14}$

The exact DSP rule constraining the fiscal gap changed from one year to another, but over our sample period it consisted in imposing a cap on the growth rate of the gap. Table 1 summarizes the evolution of the DSP over our sample period. The cap varies between a minimum of zero (no growth allowed) and a maximum of 3 percent, the benchmark being the fiscal gap two years before the actual budget year (this means that, for instance, the growth rate in 2004 is calculated with respect to the fiscal gap in 2002). Therefore our estimates will refer to the effects of a fiscal rule that allows deficits to grow rather than to stand still.

In evaluating the impact of the DSP on fiscal discipline, we therefore focus on the pattern of both deficit and fiscal gap. Constrained and unconstrained municipalities can accumulate debt, but if they run into fiscal distress they need to go through a special procedure of budget consolidation (Piano di Risanamento). One possible concern can be that relaxing fiscal rules induces expectations in our treated cities that they will be bailed out in case of situations of fiscal distress. ${ }^{15}$ While we acknowledge the possibility that changes in fiscal restraints can always be confounded with changes in expectations, both legal and anecdotal evidence are consistent with the

\footnotetext{
${ }^{13}$ See Law 23 December 1998, no. 448, article 28.

${ }^{14}$ In line with the law, we compute the fiscal gap with the formula: Fiscal Gap $=$ (Total Expenditures - Debt Service) - (Total Revenues - Transfers). See online Appendix Table A1 for more details on the definition of policy outcomes. Unfortunately, the Ministry of the Interior does not release the list of municipalities that did not comply with the rule according to its records. As discussed in Section A, we find suggestive evidence that the DSP penalties were to some extent enforced, as there is a correlation between noncompliance (as estimated in our data) and lower transfers (which are the main DSP enforcement mechanism).

${ }^{15}$ Italian cities can finance their debt through the emission of bonds (Buoni Obbligazionari Comunali), or with loans from a central administrative agency (Cassa Depositi e Prestiti), and from private banks.
} 
Table 1-Rules of the Domestic Stability Pact (DSP)

\begin{tabular}{lcc}
\hline \hline Year & Target of the DSP rules & Covered municipalities \\
\hline 1997 & None & All \\
1998 & None & All \\
1999 & Fiscal gap: zero growth & All \\
2000 & Fiscal gap: zero growth & All \\
2001 & Fiscal gap: max 3 percent growth & Above 5,000 \\
2002 & Fiscal gap: max 2.5 percent growth & Above 5,000 \\
2003 & Fiscal gap: zero growth & Above 5,000 \\
2004 & Fiscal gap: zero growth & Above 5,000 \\
\hline
\end{tabular}

Notes: The Domestic Stability Pact is a set of fiscal rules imposed by the central government to discipline the fiscal management of local governments. The main target is the Fiscal gap (see online Appendix Table A1 for details). The growth of the fiscal gap with respect to its value two years before is constrained to be either 0 or below 2.5 percent $/ 3$ percent depending on the year of the DSP.

Source: Annual national budget law (Legge Finanziaria) from 1999 to 2004

view that the Italian government made a substantial effort to keep expectations of bailouts as low as possible in the period of interest. In 2001, the Italian Constitution was revised to introduce a higher degree of fiscal decentralization while making bailouts unconstitutional. ${ }^{16}$

After 2001, all municipalities below 5,000 inhabitants were exempted by the DSP. ${ }^{17}$ The motivation for this exemption was not made explicit by the central government, but it is probably linked to the goal of providing some relief to small municipalities in the presence of economies of scale in managing the municipal government.

Fiscal rules, however, are not the only policy varying with population size at 5,000 . In particular, at this cutoff, there is a sharp increase in the wage received by the mayor and by the other members of the executive committee, based on a remuneration policy that has been in place since the early 1960s. Gagliarducci and Nannicini (2013) show that the wage increase at 5,000 attracts more educated individuals into politics and improves their performance once elected. Table 2 summarizes all the Italian policies on municipal governments relying on population thresholds over our sample period. Population size determines the size of the city council; the size of the executive committee; the electoral rule; and whether a municipality can have additional elective bodies at the neighborhood level. But only the DSP (after 2001) and the salary of local politicians display a discontinuity at the 5,000 threshold.

In 2002, regions with special autonomy (Regioni a Statuto Speciale) were allowed to set their own fiscal rules for municipal governments, and this is why we do not consider these regions in our study. Furthermore, since 2005 fiscal rules have been frequently changing from one year to another, shifting the population cutoff from

\footnotetext{
${ }^{16}$ The new article 119 of the Italian Constitution specifically forbids the increase of governmental transfers to local governments in fiscal distress. Anecdotal evidence confirms a hard-line stance by the central government toward indebted municipalities. For instance, Taranto, a medium-sized Italian city, declared bankruptcy in 2006; local newspapers reporting on the fiscal situation of the city (e.g., see Taranto Sera) stressed how the city had to undertake a multiyear repayment plan, without any help from the central government, and, after six years, almost half of the debt was still outstanding; public services and wage of public employees were suspended for some months after the bankruptcy, and local tax rates were significantly raised.

${ }^{17}$ See Law 23 December 2000, no. 388, article 53.
} 
TABle 2-Legislative Thresholds for Italian Municipalities, 1997-2004

\begin{tabular}{lccccc}
\hline \hline Population & $\begin{array}{c}\text { Wage of } \\
\text { mayor }\end{array}$ & $\begin{array}{c}\text { Wage of } \\
\text { executive committee }(\%)\end{array}$ & $\begin{array}{c}\text { Size of } \\
\text { executive committee }\end{array}$ & $\begin{array}{c}\text { Size of } \\
\text { city council }\end{array}$ & $\begin{array}{c}\text { Electoral } \\
\text { rule }\end{array}$ \\
\hline Below 1,000 & 1,291 & 15 & 4 & 12 & Single \\
$1,000-3,000$ & 1,446 & 20 & 4 & 12 & Single \\
$3,000-5,000$ & 2,169 & 20 & 4 & 16 & Single \\
$5,000-10,000$ & 2,789 & 50 & 6 & 16 & Single \\
$10,000-15,000$ & 3,099 & 55 & 6 & 20 & Single \\
$15,000-30,000$ & 3,099 & 55 & 6 & 20 & Runoff \\
$30,000-50,000$ & 3,460 & 55 & 6 & 30 & Runoff \\
$50,000-100,000$ & 4,132 & 75 & 10 & 30 & Runoff \\
$100,000-250,000$ & 5,010 & 75 & $14-16$ & 40 & Runoff \\
$250,000-500,000$ & 5,784 & 75 & 75 & $50-60$ & Runoff \\
Above 500,000 & 7,798 & Runoff \\
\hline
\end{tabular}

Notes: Policies varying at different legislative thresholds in the period 1999-2004. Population is the number of resident inhabitants as measured by the last available census. Wage of mayor and Wage of executive committee refer to the monthly gross wage of the mayor and the members of the executive committee, respectively; the latter is expressed as a percentage of the former, which refers to 2000 and is measured in euros. Size of executive committee is the maximum allowed number of executives appointed by the mayor. Size of city council is the number of seats in the city council. The wage thresholds at 1,000 and 10,000 were introduced in 2000; all of the other thresholds date back to 1960 . Since 1993, the Electoral rule for the mayor is plurality with either single round or runoff.

5,000 to 3,000 and back, and replacing the fiscal gap requirement with expenditure caps in some years. This is the reason why we focus our empirical evaluation on the period from 1997 to 2004.

In the next section, we explain how we exploit our setting to identify the effect of fiscal restraints on fiscal discipline.

\section{Econometric Framework}

\section{A. Setup}

Based on the institutional framework discussed above, two treatments sharply change at the relevant threshold: the wage of the mayor (and of the executive officers) and fiscal rules. Define $W_{i t}$ as the first treatment for municipality $i$ at time $t$, equal to one if the wage is low and equal to zero otherwise; also define $R_{i t}$ as the second treatment, equal to one if fiscal rules are relaxed and equal to zero if they are still binding. Mayors of municipalities with population size $\left(P_{i t}\right)$ below the threshold $P_{c}=5,000$ have a lower salary for every year of the sample period, while the relaxation of fiscal rules is introduced at time $t_{0}$ for municipalities below the same threshold. Population size is measured by the last available census (Gagliarducci and Nannicini 2013, Calzolari et al. 2014). The assignment mechanism for both treatments can therefore be described as follows:

$$
\begin{aligned}
& W_{i t}= \begin{cases}1 & \text { if } P_{i t}<P_{c} \\
0 & \text { otherwise, }\end{cases} \\
& R_{i t}= \begin{cases}1 & \text { if } P_{i t}<P_{c} \text { and } t \geq t_{0} \\
0 & \text { otherwise. }\end{cases}
\end{aligned}
$$


Define $Y_{i t}(w, r)$ as the potential policy outcomes if $W_{i t}=w$ and $R_{i t}=r$, with $w=0,1$ and $r=0,1$. The observed outcome is therefore equal to $Y_{i t}=W_{i t} R_{i t} Y_{i t}(1,1)+W_{i t}\left(1-R_{i t}\right) Y_{i t}(1,0)+\left(1-W_{i t}\right) R_{i t} Y_{i t}(0,1)+$ $\left(1-W_{i t}\right)\left(1-R_{i t}\right) Y_{i t}(0,0)$.

In this setting, we aim at identifying the causal effect of $R_{i t}$ on $Y_{i t}$. Borrowing the notation from Hahn, Todd, and Van der Klaauw (2001), we define $Z^{-}$ $\equiv \lim _{p \rightarrow P_{c}^{-}} E\left[Z_{i t} \mid P_{i t}=p, t \geq t_{0}\right]$ and $Z^{+} \equiv \lim _{p \rightarrow P_{c}^{+}} E\left[Z_{i t} \mid P_{i t}=p, t \geq t_{0}\right]$, with $Z=Y, Y(1,1), Y(1,0), Y(0,1), Y(0,0)$. Hahn, Todd, and Van der Klaauw (2001) derive precise conditions under which the cross-sectional Regression Discontinuity (RD) estimator after $t_{0}$, defined as $\hat{\tau}_{R D} \equiv Y^{-}-Y^{+}$, would identify the average treatment effect of $R_{i t}$ at the threshold-i.e., for $P_{i t}=P_{c}$-if fiscal rules were the only treatment sharply changing at $P_{c}$. In our setting, however, standard continuity conditions are not enough for identification, because of the confounding treatment $W_{i t}$.

Even if we assume that all potential outcomes $E\left[Y_{i t}(w, r) \mid P_{i t}=p, t \geq t_{0}\right]$, with $w=0,1$ and $r=0,1$, are continuous in $p$ at $P_{c}$, we have that

$$
\begin{aligned}
\hat{\tau}_{R D} \equiv & Y^{-}-Y^{+}=Y(1,1)^{-}-Y(0,0)^{+} \\
= & {\left[Y(1,1)^{-}-Y(1,0)^{-}\right]+\left[Y(1,0)^{+}-Y(0,0)^{+}\right] } \\
= & E\left[Y(1,1)_{i t}-Y(1,0)_{i t} \mid P_{i t}=P_{c}, t \geq t_{0}\right] \\
& +E\left[Y(1,0)_{i t}-Y(0,0)_{i t} \mid P_{i t}=P_{c}, t \geq t_{0}\right],
\end{aligned}
$$

where the first term in the right-hand side captures one of the potential causal effects of interest (namely, the average treatment effect of relaxing fiscal rules in cities where mayors are poorly paid) and the second term captures a "selection bias" (namely, the average treatment effect of reducing mayors' wage in cities where fiscal rules are binding). ${ }^{18}$ As a result, the cross-sectional RD estimator provides a biased estimate of the average treatment effect of relaxing fiscal rules in a neighborhood of the threshold, because the effects of the two (confounded) treatments cannot be disentangled between each other.

\section{B. Identification and Diagnostics}

We now show how to overcome the identification problem discussed above. Information on the pretreatment period $\left(t<t_{0}\right)$ allows us to remove the selection bias under local assumptions. Analogously to the posttreatment period, for the pretreatment period we define: $\tilde{Z}^{-} \equiv \lim _{p \rightarrow P_{c}^{-}} E\left[Z_{i t} \mid P_{i t}=p, t<t_{0}\right]$ and $\tilde{Z}^{+}$ $\equiv \lim _{p \rightarrow P_{c}^{+}} E\left[Z_{i t} \mid P_{i t}=p, t<t_{0}\right]$, with $Z=Y, Y(1,1), Y(1,0), Y(0,1), Y(0,0)$.

\footnotetext{
${ }^{18}$ Obviously, the fact that we refer to the second term as "selection bias" is just a matter of convention, as we are after the treatment effect of relaxing fiscal rules. As a matter of fact, both terms are average treatment effects of two (confounded) policies.
} 
To identify the causal effect of relaxing fiscal rules, we exploit both the discontinuous variation at $P_{c}$ and the time variation after $t_{0}$ :

$$
\hat{\tau}_{D D} \equiv\left(Y^{-}-Y^{+}\right)-\left(\tilde{Y}^{-}-\tilde{Y}^{+}\right) .
$$

We call $\hat{\tau}_{D D}$ "difference-in-discontinuities" estimator (shortly, "diff-in-disc"), because it rests on the intuition of combining a difference-in-differences strategy and an RD design.

Alternative approaches in the literature have exploited the longitudinal nature of the data in an RD framework, such as the fixed-effect RD estimator in Pettersson-Lidbom (2012), the first-difference RD estimator in Lemieux and Milligan (2008), or the dynamic RD design in Cellini, Ferreira, and Rothstein (2010). All of these estimators, however, are different from ours. In their setups, treatment assignment changes over time and identification rests on within-unit variation, while in our case identification rests on the difference between two cross-sectional estimators. We are aware that other empirical studies have already implemented what we call diff-in-disc design, but we now provide precise identification assumptions for this approach and propose diagnostics tools that directly stem from these assumptions. 19

ASSUMPTION 1: All potential outcomes $E\left[Y_{i t}(w, r) \mid P_{i t}=p, t \geq t_{0}\right]$ and $E\left[Y_{i t}(w, r) \mid P_{i t}=p, t<t_{0}\right]$, with $w=0,1$ and $r=0,1$, are continuous in $p$ at $P_{c}$.

ASSUMPTION 2: The effect of the confounding policy $W_{i t}$ at $P_{c}$, in the case of no treatment, $\left(R_{i t}=0\right)$ is constant over time: $Y(1,0)-Y(0,0)=\tilde{Y}(1,0)-$ $\tilde{Y}(0,0) \cdot{ }^{20}$

Assumption 2 requires the effect of the confounding policy discontinuity $W_{i t}$ at $P_{c}$ not to vary with time. In other words, it requires observations just below and just above $P_{c}$ to be on a (local) parallel trend in the absence of the new policy $R_{i t}$. This is similar to the standard identifying assumption for difference-in-differences but is more local, as it must be met only in a neighborhood of the policy threshold. ${ }^{21}$ To indirectly test for this assumption, in Section IV, we estimate the pattern of the discontinuities in $Y_{i t}$ before $t_{0}$ and show that observations just below and just above $P_{c}$ were not on differential trends before the policy shift. Another test to validate the

\footnotetext{
${ }^{19}$ For examples of diff-in-disc designs, see Lalive (2008), Campa (2011), Leonardi and Pica (2013), and Casas-Arce and Saiz (2015). Our econometric strategy also relates to evaluation designs that exploit the comparison between different discontinuities across space, such as in different US states (see Dickert-Conlin and Elder 2010) or for politicians facing different term limits (see Gagliarducci and Nannicini 2013).

${ }^{20}$ Note that, because of Assumption 1 , we can now write: $Z^{+}=Z^{-} \equiv Z$ and $\tilde{Z}^{+}=\tilde{Z}^{-} \equiv \tilde{Z}$, with $Z=Y, Y(1,1), Y(1,0), Y(0,1), Y(0,0)$.

${ }^{21}$ Indeed, in our empirical setting, the difference-in-differences assumption of parallel trend in the all sample is unlikely to be satisfied (see the evidence discussed in the next section).
} 
plausibility of this assumption coincides with checking whether any manipulation of the running variable changes (or arises) over time.22

It is easy to show that, under the above assumptions, the diff-in-disc estimator identifies the (local) causal effect of relaxing fiscal rules $\left(R_{i t}\right)$ in a neighborhood of the threshold $\left(P_{i t}=P_{c}\right)$ and for cities where politicians' wages are low $\left(W_{i t}=1\right)$.

PROPOSITION 1: Under Assumption 1 and Assumption 2, the diff-in-disc estimator $\hat{\tau}_{D D}$ identifies the average treatment effect: $E\left[Y_{i t}(1,1)-Y_{i t}(1,0) \mid P_{i t}=P_{c}\right]$.

\section{PROOF:}

$$
\begin{aligned}
\hat{\tau}_{D D} \equiv & \left(Y^{-}-Y^{+}\right)-\left(\tilde{Y}^{-}-\tilde{Y}^{+}\right)=\left[Y(1,1)^{-}-Y(0,0)^{+}\right] \\
& -\left[\tilde{Y}(1,0)^{-}-\tilde{Y}(0,0)^{+}\right]=Y(1,1)-Y(0,0)-Y(1,0)+Y(0,0) \\
& =Y(1,1)-Y(1,0)=E\left[Y_{i t}(1,1)-Y_{i t}(1,0) \mid P_{i t}=P_{c}\right] .
\end{aligned}
$$

This result allows us to identify a causal effect of the treatment of interest under plausible conditions. Yet, the estimand only refers to cities with poorly paid mayors (that is, to cities that also receive the confounding treatment). To identify a more general estimand with the diff-in-disc estimator, we need to make a further assumption.

ASSUMPTION 3: The effect of the treatment $R_{i t}$ at $P_{c}$ does not depend on the confounding policy $W_{i t}: Y(1,1)-Y(1,0)=Y(0,1)-Y(0,0) \equiv Y(1)-Y(0)$.

It is straightforward to extend the result in Proposition 1 and show that, under the above assumption, the diff-in-disc estimator identifies the (local) causal effect of relaxing fiscal rules in a neighborhood of the threshold, that is, the standard estimand in RD designs: $E\left[Y_{i t}(1,1)-Y_{i t}(1,0) \mid P=P_{c}\right]=E\left[Y_{i t}(0,1)-Y_{i t}(0,0) \mid P=\right.$ $\left.P_{c}\right] \equiv E\left[Y_{i t}(1)-Y_{i t}(0) \mid P=P_{c}\right]$.

This third (homogeneity) assumption states that there must be no interaction between the treatment and the confounding policy. In our institutional setting, this assumption would be violated if mayors just below and just above $P_{c}$, who are paid differently, reacted to the relaxation of fiscal rules in different ways. In Section IV, under the maintained hypothesis that Assumption 2 holds, we directly test Assumption 3 exploiting the introduction of fiscal rules for all municipalities in 1999. In fact, if Assumption 3 were satisfied, a falsification test implementing the diff-in-disc estimator in 1999 would deliver a zero effect.

\footnotetext{
${ }^{22}$ Specifically, in Section IV, we extend the cross-sectional test of continuity of the density at $P_{c}$ (see McCrary 2008 ) to test for the continuity of the difference in the densities before and after $t_{0}$. We also implement diff-in-disc estimations with time-invariant characteristics as outcomes, so as to indirectly test for changes in the pattern of manipulative sorting. As a further check in this direction, we include time-invariant characteristics and year fixed effects as covariates in the baseline diff-in-disc estimations; in the absence of manipulative sorting, point estimates are expected to remain similar and accuracy to increase.
} 
Finally, note that-based on the institutions described in the previous sectionour diff-in-disc design can only identify the effect of relaxing fiscal rules for small Italian municipalities. Therefore, interpreting our estimates as the effect of imposing fiscal rules in the same setting would require an additional symmetry assumption.

\section{Estimation}

The diff-in-disc estimator can be implemented by estimating the boundary points of four regression functions of $Y_{i t}$ on $P_{i t}$ : two on both sides of $P_{c}$, both before and after $t_{0}$. We apply a local linear regression, following Gelman and Imbens (2014).23 The method consists in fitting linear regression functions to the observations distributed within a distance $h$ on either side of $P_{c}$, both before and after $t_{0}$. Formally, we restrict the sample to cities in the interval $P_{i t} \in\left[P_{c}-h, P_{c}+h\right]$ and estimate the model

$$
\begin{aligned}
Y_{i t}= & \delta_{0}+\delta_{1} P_{i t}^{*}+S_{i}\left(\gamma_{0}+\gamma_{1} P_{i t}^{*}\right)+T_{t}\left[\alpha_{0}\right. \\
& \left.+\alpha_{1} P_{i t}^{*}+S_{i}\left(\beta_{0}+\beta_{1} P_{i t}^{*}\right)\right]+\xi_{i t},
\end{aligned}
$$

where $S_{i}$ is a dummy for cities below 5,000 capturing treatment status, $T_{t}$ an indicator for the posttreatment period, and $P_{i t}^{*}=P_{i t}-P_{c}$ the normalized population size. Standard errors are clustered at the city level. The coefficient $\beta_{0}$ is the diff-in-disc estimator and identifies the treatment effect of relaxing fiscal rules, as the treatment is $R_{i t}=S_{i} \cdot T_{t}$. We present the robustness of our results to multiple bandwidths $h$, optimally computed first following the algorithm developed by Calonico, Cattaneo, and Titiunik (2014a, b), and then implementing the cross-validation method proposed by Ludwig and Miller (2007). ${ }^{24}$

\section{Data}

We use administrative data from the Italian Ministry of the Interior (Ministero dell'Interno) containing information at the municipality level on the universe of municipal financial reports, municipal tax rates, electoral outcomes, and individual characteristics of the mayor. Based on the local nature of our diff-in-disc design, we restrict the sample to Italian municipalities between 3,500 and 7,000 inhabitants. ${ }^{25}$

\footnotetext{
${ }^{23}$ See also Imbens and Lemieux (2008), Van der Klaauw (2008), and Lee and Lemieux (2010).

${ }^{24}$ In a previous working paper version of the paper (Grembi, Nannicini, and Troiano 2012), we show that our estimates are robust if we adopt a spline polynomial approximation. That method uses all observations and chooses a flexible functional form to fit the relationship between $Y_{i t}$ and $P_{i t}$ on either side of $P_{c}$, both before and after $t_{0}$ :

$$
Y_{i t}=\sum_{k=0}^{q}\left(\delta_{k} P_{i t}^{* k}\right)+S_{i} \sum_{k=0}^{q}\left(\gamma_{k} P_{i t}^{* k}\right)+T_{t}\left[\sum_{k=0}^{q}\left(\alpha_{k} P_{i t}^{* k}\right)+S_{i} \sum_{k=0}^{q}\left(\beta_{k} P_{i t}^{* k}\right)\right]+\xi_{i t},
$$

where $\beta_{0}$ is again the diff-in-disc estimator identifying the treatment effect of relaxing fiscal rules.

${ }^{25}$ We restrict the sample to the interval 3,500-7,000 to stay relatively far from the 3,000 threshold, where other policies change (see Table 2), and to balance the sample size on either side of the 5,000 threshold. All the results are robust to this interval choice, i.e., they are virtually unchanged for alternative choices, such as 3,250-6,750; $3,000-7,000 ; 3,500-6,500 ; 4,000-6,000$; and 3,500-7,500.
} 
For the reason discussed in Section I, we drop municipalities in regions with special autonomy. This leaves us with a final sample of 1,050 municipalities for a total of 6,300 observations from 1999 to 2004. Among them, 555 municipalities are treated after 2001 and 495 are in the control group. Our sample contains about 13 percent of all Italian municipalities and about 8 percent of the national population.

The population size comes either from the 1991 or from the 2001 census. Because the relaxation of the DSP was decided in December 2000, it is very unlikely that municipalities had the time to influence their census population and sort below the 5,000 threshold, and it is also unlikely that elected officials wanted to do that at the price of cutting their wage. In Section B, we formally test for manipulative sorting below 5,000 before/after 2001 by comparing population size in the 1991 and 2001 census.

The main variables of interest are the municipal financial report's categories. To measure fiscal discipline, we evaluate the deficit (total expenditures minus total revenues) and the fiscal gap (total expenditures minus total revenues, net of transfers, and debt service), which is the target of the DSP. We divide expenditures into current outlays (including personnel expenditure), capital outlays (mostly investments), and debt service; and we divide revenues into municipal taxes, fees and tariffs, transfers from the central government, and other revenues. The main tax instruments decided by municipal governments are the real estate tax rate on home property (ICI), providing about 50 percent of their tax revenues, and the municipal surcharge on the personal income tax (IRPEF), amounting to about 10 percent of tax revenues. ${ }^{26}$ See the online Appendix Table A1 for precise definitions and data sources of all variables from the municipal financial reports.

One possible concern in evaluating the reaction of policies and tax instruments to fiscal rules might be that mayors have very little autonomy in adjusting local revenues or expenditure, but this is not the case for Italian municipalities. On the revenues side, over our sample period, mayors could vary ICI within a bracket from 0.4 to 0.7 percent of the legal home value, and the IRPEF surcharge within a bracket from 0 to 0.5 percent of taxable income. ${ }^{27}$ And they were also free to set other local taxes (such as those on building rights or the occupation of public areas) or fees and tariffs for the services they provided (such as waste management or child care). Additionally, Italian towns are characterized by a sizable level of tax evasion, which the mayor can decide to fight. ${ }^{28}$

On the expenditure side, municipalities also have room for adjustment because about one-third of expenditures are classified as not rigid (that is, not attributable to payroll expenses and debt service). For instance, one way to reduce expenditures without affecting the level of services is outsourcing (e.g., child care provided by private firms with more labor flexibility and lower costs although the financing

\footnotetext{
${ }^{26}$ Bordignon, Nannicini, and Tabellini (2013) also use ICI as the main policy tool of Italian municipalities.

${ }^{27}$ One additional concern can be that mayors comply with the rule by simply manipulating legal home value. However, legal home value is not determined or updated by mayors, as indicated by the DPR 22 December 1986 , no. 917. Only in 2005, not in our sample, the Law 23 December 2005, no. 266 gave to municipalities some weak power of requesting the update of the assessed value of the real estate tax base.

${ }^{28}$ Casaburi and Troiano (2016) find that in 2007 over 2 million Italian buildings were not registered in the cadastral maps and thus were not part of the tax base for real estate and income tax.
} 
Table 3-Outcome Variables, Descriptive Statistics

\begin{tabular}{lcc}
\hline \hline & $\begin{array}{c}\text { Municipalities } \\
\text { above 5,000 }\end{array}$ & $\begin{array}{c}\text { Municipalities } \\
\text { below 5,000 }\end{array}$ \\
\hline $\begin{array}{l}\text { Panel A. Fiscal discipline } \\
\text { Deficit }\end{array}$ & 11.080 & 15.457 \\
Fiscal gap & 170.724 & 208.624 \\
Panel B. Expenditures & & \\
Current outlays & 475.312 & 502.181 \\
Capital outlays & 438.838 & 508.794 \\
Debt service & 29.139 & 30.107 \\
Panel C. Revenues & & \\
Taxes & 194.887 & 175.825 \\
Fees and tariffs & 56.601 & 58.938 \\
Central transfers & 188.783 & 223.274 \\
Other revenues & 491.938 & 567.589 \\
Panel D. Tax instruments & & \\
Real estate tax rate & 0.587 & 0.576 \\
Income tax surcharge & 0.309 & 0.309 \\
Observations & 2,970 & 3,330 \\
\hline
\end{tabular}

Notes: Municipalities between 3,500 and 7,000 inhabitants; budget years between 1999 and 2004. The average values of per capita policy outcomes are in 2009 euros. The real estate tax rate and the income tax surcharge are in percentage points; the former can vary from 0.4 to 0.7 percent; the latter can vary from 0 to 0.5 percent.

remains public). Furthermore, Bandiera, Prat, and Valletti (2009) show how similar Italian municipalities can pay very differently for similar goods, and they interpret this as evidence of passive waste. This implies that, even if all current expenditures were rigid (and this is certainly not the case), mayors would still have the ability to reduce passive waste in order to adjust the fiscal gap.

Our dataset also contains time-invariant information on each municipality (geographic location, area size in $\mathrm{km}^{2}$, sea level in meters), as well as time-varying information on the elected mayor (age, years of schooling, tenure in office, term limit), on the socioeconomic environment (taxable income of resident inhabitants, age structure of the population), and on the political environment (number of political parties in the city council).

Table 3 provides descriptive statistics on the main outcome variables (policy outcomes and tax instruments) for cities below and above 5,000 inhabitants. All variables are per capita and expressed in real terms (with 2009 as base year); tax rates are in percentage points. Municipalities below (above) 5,000 manage an annual budget equal to almost 1,041 (943) euros per capita in terms of expenditures, and the deficit amounts to about 15 (11) euros. Taxes are only slightly lower than 20 percent of total revenues and higher in municipalities above 5,000. The main tax rates on ICI and the IRPEF surcharge, however, are fairly similar for municipalities in the two groups. Please note that transfers amount to about 200 euro per capita, which is close to the difference between deficit and fiscal gap.

As a benchmark, note that applying a difference-in-differences strategy to our dataset delivers the expected result: relaxing fiscal rules increases the deficit by 6.276 euros per capita and the fiscal gap by 48.278 euros per capita in a specification 
without municipality fixed effects, and by 5.279 and 16.669 with fixed effects, where both estimates on deficit are statistically significant at a 5 percent level and those on the fiscal gap at a 1 percent level (see Table A2). Those coefficients should be interpreted with caution, because their identification relies on assuming that small cities are a good counterfactual for larger cities. This is a strong assumption, which is violated in our setting because population affects the trends, and not only the levels, of public policies. In online Appendix Figure A1 we show that in a difference-in-differences design the parallel pre-trends assumption is violated for four of our budget items (capital expenditures, taxes, other revenues, and fees and transfers).

In the next section, we discuss the results of the diff-in-disc design.

\section{Empirical Results}

\section{A. Effect of Relaxing Fiscal Rules on Policy Outcomes}

Table 4 contains the main (diff-in-disc) estimation results. The main outcomes of interest are the two measures of fiscal discipline: deficit and fiscal gap. While the latter is the main target of the DSP, we believe that the former should be the real variable of policy interest. For each outcome variable, we present our baseline local linear regression estimates as in equation (1), with two different types of optimal bandwidth. 29

The impact of relaxing rules on the deficit is positive and significant both in statistical and in economic terms. The DSP relaxation increases the deficit by about 20 euros per capita with respect to a baseline situation of balanced budget. The deficit created by the relaxation of the DSP is also substantial from an economic point of view, as it amounts to about 2 percent of total expenditures. This effect is driven by a higher fiscal gap of about 30 percent. Both these effects are statistically significant at standard levels in all specifications, while the point estimates seem to depend from the selected bandwidth. The relatively large difference between the coefficient on the deficit and on the fiscal gap is mainly explained by a difference in transfers, which is consistent, as discussed below, with the possibility that noncompliant municipalities subject to the DSP receive lower transfers.

These estimation results on fiscal discipline are consistent with the descriptive graphs shown in Figure 1 where we draw scatters and polynomial fits of the differences between each post-2001 outcome value and each pre-2001 value. These graphs allow us to see whether those differences exhibit a discontinuity at the 5,000 threshold. We see that both variables measuring fiscal discipline exhibit a sharp jump when moving from the left to the right of the threshold in the whole sample. Furthermore, in the top graphs of Figure 2, we shed some light on the timing of the effect to provide evidence that high and low paid mayors were on parallel trends

\footnotetext{
${ }^{29}$ Optimal bandwidths are calculated as either in Calonico, Cattaneo, and Titiunik (2014a, b) or in Ludwig and Miller (2007). Results are robust to the use of predetermined bandwidths (i.e., 250, 500, 750, and 1,000) or spline polynomial with different orders (i.e., third and fifth). In a previous version of the paper, Grembi, Nannicini and Troiano (2012), we presented the results for the spline third- and fourth-order polynomials.
} 
Table 4-Effect of Relaxing Fiscal Rules, Diff-IN-Disc Estimates

\begin{tabular}{|c|c|c|c|c|c|c|}
\hline & Deficit & Fiscal gap & $\begin{array}{l}\text { Current } \\
\text { outlays }\end{array}$ & $\begin{array}{l}\text { Capital } \\
\text { outlays }\end{array}$ & $\begin{array}{c}\text { Debt } \\
\text { service }\end{array}$ & \\
\hline \multicolumn{7}{|c|}{ Panel A: Fiscal discipline and expenditures } \\
\hline Calonico et al. (2014) & $\begin{array}{l}17.495 \\
(7.737)\end{array}$ & $\begin{array}{c}59.468 \\
(32.079)\end{array}$ & $\begin{array}{c}-47.698 \\
(59.522)\end{array}$ & $\begin{array}{c}102.557 \\
(101.152)\end{array}$ & $\begin{array}{c}-2.607 \\
(8.057)\end{array}$ & \\
\hline$h$ & 600 & 513 & 443 & 427 & 404 & \\
\hline Observations & 2,414 & 2,136 & 1,828 & 1,724 & 1,646 & \\
\hline Cross validation & $\begin{array}{c}9.454 \\
(4.343)\end{array}$ & $\begin{array}{c}48.469 \\
(23.315)\end{array}$ & $\begin{array}{r}-10.665 \\
(32.756)\end{array}$ & $\begin{array}{l}-4.221 \\
(83.336)\end{array}$ & $\begin{array}{c}-2.096 \\
(3.587)\end{array}$ & \\
\hline$h$ & 1,498 & 833 & 979 & 944 & 1,202 & \\
\hline Observations & 5,858 & 3,438 & 4,112 & 3,974 & 4,908 & \\
\hline \multirow[t]{2}{*}{ Mean } & 13.393 & 190.757 & 489.515 & 475.815 & 29.651 & \\
\hline & Taxes & $\begin{array}{l}\text { Fees and } \\
\text { tariffs }\end{array}$ & $\begin{array}{c}\text { Central } \\
\text { transfers }\end{array}$ & $\begin{array}{c}\text { Other } \\
\text { revenues }\end{array}$ & $\begin{array}{l}\text { Real estate } \\
\text { tax rate }\end{array}$ & $\begin{array}{c}\text { Income tax } \\
\text { surcharge }\end{array}$ \\
\hline \multicolumn{7}{|c|}{ Panel B: Revenues and tax instruments } \\
\hline Calonico et al. (2014) & $\begin{array}{r}-76.083 \\
(32.597)\end{array}$ & $\begin{array}{l}-2.879 \\
(10.140)\end{array}$ & $\begin{array}{c}35.001 \\
(27.634)\end{array}$ & $\begin{array}{l}-21.900 \\
(120.248)\end{array}$ & $\begin{array}{c}-0.050 \\
(0.026)\end{array}$ & $\begin{array}{c}-0.070 \\
(0.039)\end{array}$ \\
\hline$h$ & 378 & 505 & 564 & 399 & 435 & 441 \\
\hline Observations & 1,536 & 2,104 & 2,286 & 1,622 & 1,782 & 1,310 \\
\hline Cross validation & $\begin{array}{r}-34.748 \\
(20.166)\end{array}$ & $\begin{array}{c}1.413 \\
(7.199)\end{array}$ & $\begin{array}{c}32.938 \\
(21.721)\end{array}$ & $\begin{array}{r}-81.308 \\
(62.926)\end{array}$ & $\begin{array}{c}-0.027 \\
(0.016)\end{array}$ & $\begin{array}{c}-0.044 \\
(0.026)\end{array}$ \\
\hline$h$ & 684 & 795 & 833 & 1,498 & 907 & 871 \\
\hline Observations & 2,810 & 3,238 & 3,438 & 5,858 & 3,806 & 2,594 \\
\hline Mean & 184.811 & 57.836 & 207.014 & 531.925 & 0.581 & 0.309 \\
\hline
\end{tabular}

Notes: Municipalities between 3,500 and 7,000 inhabitants; budget years between 1999 and 2004. Diff-in-disc estimates of the impact of relaxing fiscal rules on policy outcomes and tax instruments below 5,000 after 2001. Estimation method: local linear regression with two optimal bandwidth $h$, as in equation (1). The optimal bandwidth $h$ is estimated either following Calonico, Cattaneo, and Titiunik (2014a, b), or implementing the cross-validation algorithm proposed by Ludwig and Miller (2007). All policy outcomes are per capita and in 2009 euros.

around the neighborhood of the 5,000 threshold. ${ }^{30}$ The evidence is consistent for both deficit and fiscal gap, as there is a change in the slope of the coefficients only after 2001. Most importantly, the cross-sectional RD estimates in 1999 and 2000 show that cities just below and just above 5,000 were on parallel trends before the policy shift. The fact that the timing of change is sharper for fiscal gap than for deficit could potentially be explained by the enforcement of the law through penalties. This robustness check also indirectly suggests that our policy was not anticipated in previous years.

\footnotetext{
${ }^{30}$ The preexisting discontinuities are consistent with the results of Gagliarducci and Nannicini (2013), who find that low paid mayors are more likely to engage in redistribution, which appears to be financed with both higher deficits and attracting more transfers.
} 

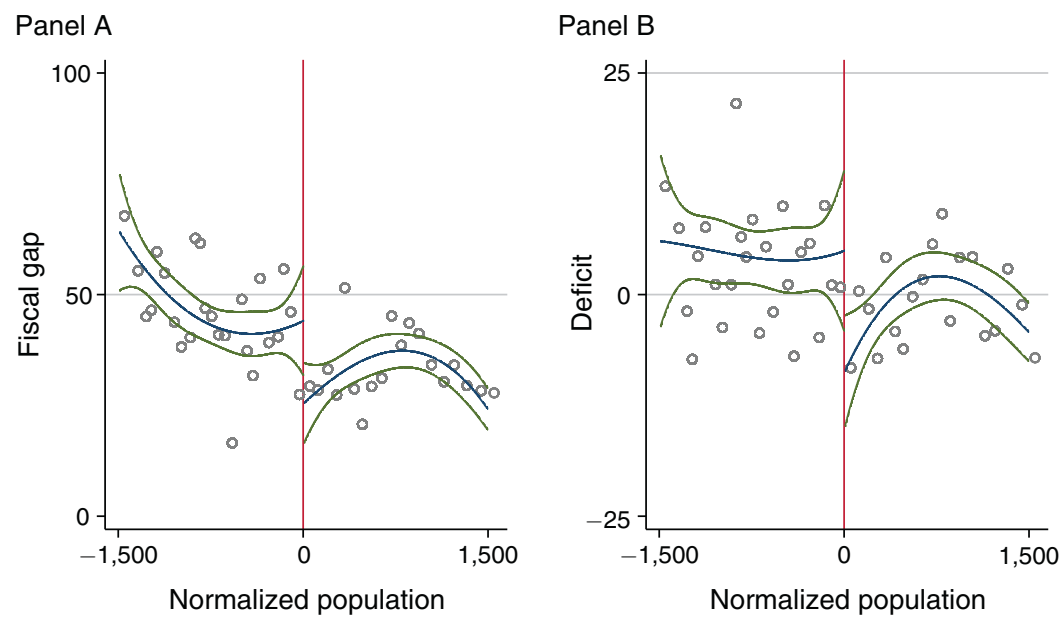

Figure 1. Difference-In-Discontinuities for Deficit and Fiscal Gap (1)

Notes: Vertical axis: difference of each post-rule (i.e., 2001, 2002, 2003, and 2004) outcome value and each pre-rule (i.e., 1999 and 2000) outcome value. Horizontal axis: actual population size minus 5,000. The central line is a spline third-order polynomial fit; the lateral lines represent the 95 percent confidence interval. Scatter points are averaged over intervals of 50 inhabitants.

It should be noted that the magnitude of our effects is sensitive to the bandwidth chosen, as can be seen in the two graphs plotted at the bottom of Figure 2 (panels $\mathrm{C}$ and $\mathrm{D}$ ). If one interprets bandwidth choice as a tradeoff between accuracy and consistency (with smaller bandwidths reducing the precision of the estimates but also removing selection bias), it is instructive to note that smaller bandwidths are associated with both larger confidence intervals, as expected, and larger point estimates, accordingly with the expected direction of the bias. It should be noted that the difference-in-differences estimates are closer to the diff-in-disc ones with larger bandwidths, and that the statistical significance is lost at a bandwidth of a population size of about 1,000 inhabitants for fiscal gap and is never lost for deficit.

One of the advantages of our setting is the availability of homogeneous financial reports about the policies the Italian municipalities, and the availability of administrative data about tax rates. In the last three columns of panel A, Table 4, we begin investigating the composition of the fiscal adjustment and we consider the expenditures side. We find that the coefficient on the expenditures variables are not statistically different from zero, although the large standard errors don't allow drawing a definite conclusion. However, it is reassuring to note that the graphical evidence in both Figures 3 and 4 suggests that the large standard errors may be due to outliers, and that no sizable discontinuities are detected in the expenditures outcomes via visual inspection, with the exclusion of the debt service (whose point estimate is, however, not statistically different from zero in Table 4, probably because of the different choice of the bandwidth and control function).

In panel B, we find that tax revenues are lower by about 20 to 45 percent in unconstrained municipalities. Lower tax revenues are the result of lower tax rates decided by the municipal government (see panel B of Table 4). Cities for which fiscal rules are relaxed have a 14 percent lower real estate tax rate and a 30 percent 
Panel A

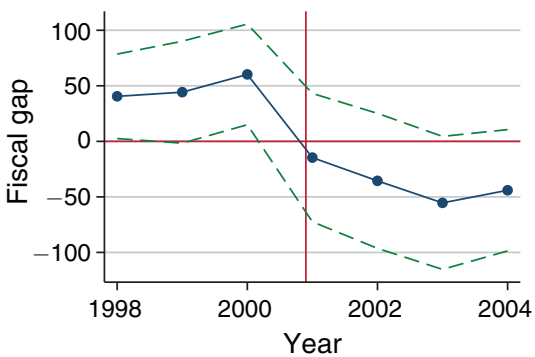

Panel C

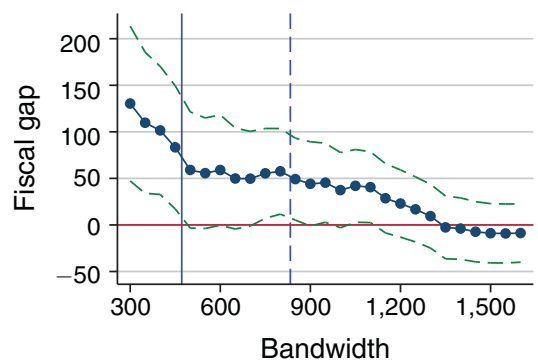

Panel B

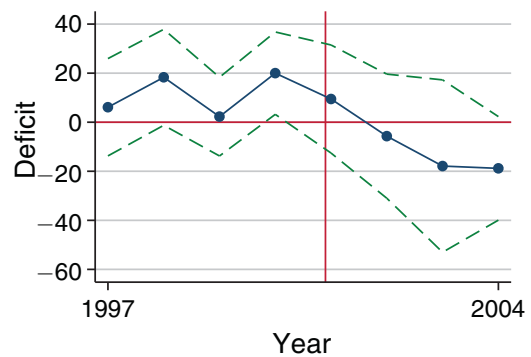

Panel D

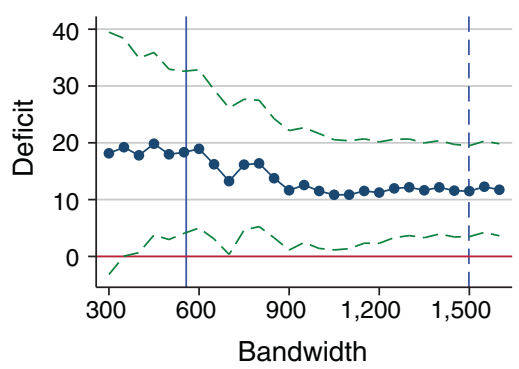

Figure 2. Difference-In-Discontinuities for Deficit and Fiscal Gap (2)

Notes: Top graphs: yearly RD coefficients. Vertical axis: point estimates of local linear regressions with optimal bandwidth computed following Calonico, Cattaneo, and Titiunik (2014a,b). Horizontal axis: year. The central line is the point estimate; the lateral lines represent the 95 percent confidence interval. Bottom graphs: difference-in-discontinuities. Vertical axis: diff-in-disc coefficients. Horizontal axis: bandwidth used to estimate the reported diff-in-disc coefficients.

lower income tax surcharge. Other revenues do not seem to be affected by the relaxation of fiscal restraints. ${ }^{31}$ In Figure 5, we confirm that the (local) parallel trend assumption is also satisfied for all our other financial report items. ${ }^{32}$

Also on the side of revenues, central transfers seem to be higher for unconstrained municipalities, although point estimates are not statistically significant. The large standard errors do not allow us to draw a definitive conclusion about the effect of relaxing the restraints on transfers. However, even if transfers increased as a result of the relaxation of the restraint, that result would not be able to explain the above impact of relaxing fiscal rules on fiscal discipline, because it would go in the opposite direction (that is, local governments running higher deficits receive larger transfers), and it would be consistent with the design of the law, which allows the central government to cut transfers as an enforcement mechanism. This conjecture

\footnotetext{
${ }^{31}$ Other revenues include transfers from the European Union, other transfers, mortgages from administrative agencies, revenues coming from private properties owned by the municipality. Even if the standard errors for other revenues are bigger than the rest of our variables, visual inspection of the corresponding graph in Figure 3 reveals that standard errors are driven up by an outlier in this category. Repeating our analysis without this outlier consistently reduces the standard errors without affecting the other outcomes.

${ }^{32}$ We also investigate how the relaxation of the restraint affects total revenues and total expenditures. We don't detect a statistically significant effect on total revenues and total expenditures.
} 
Panel A
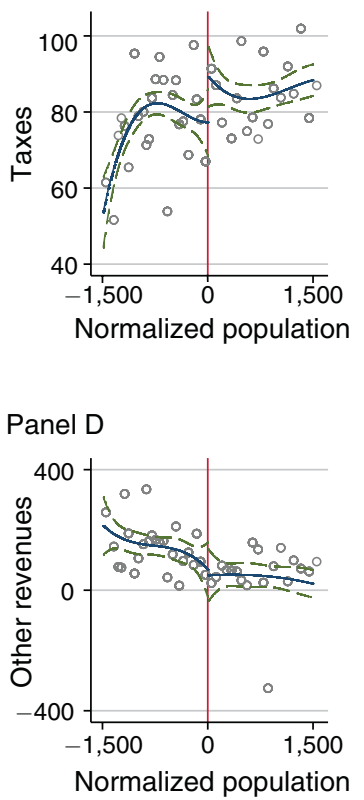

Panel B

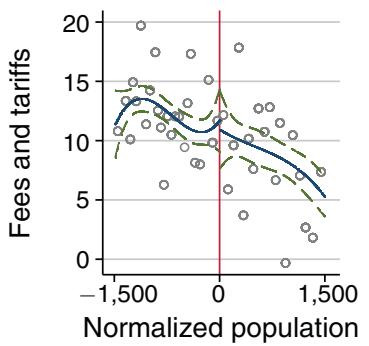

Panel E

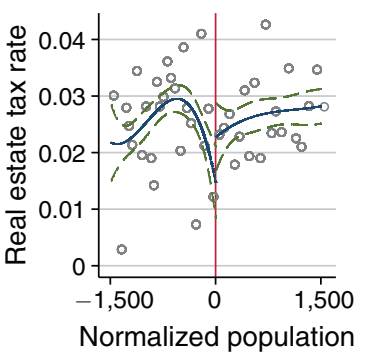

Panel C

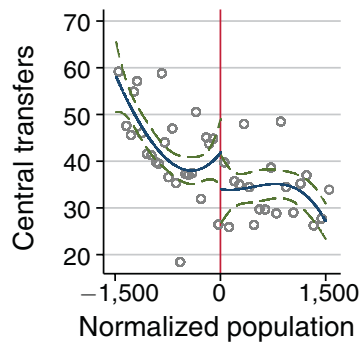

Panel F

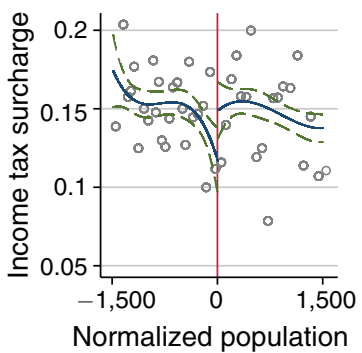

Figure 3. DifFerence-IN-Discontinuities for Revenues Outcomes

Notes: Difference-in-discontinuities. Vertical axis: difference of each post-rule (i.e., 2001, 2002, 2003, and 2004) outcome value and each pre-rule (i.e., 1999 and 2000) outcome value. Horizontal axis: actual population size minus 5,000 . The central line is a spline third-order polynomial fit; the lateral lines represent the 95 percent confidence interval. Scatter points are averaged over intervals of 50 inhabitants.

is consistent with our data. Although the Italian government did not release the official list of complying and noncomplying municipalities, we can estimate compliance status in every year by applying the official rule summarized in Table 1 to our data. We find that complying municipalities amount to 68 percent of the total, and noncomplying municipalities are also present around the 5,000 threshold, where the estimated compliance status shows a sharp discontinuity of about 40 percent. ${ }^{33}$ Future transfers appear to be strongly correlated with compliance status: in a specification that controls for municipality and year fixed effects, central transfers are larger by about 10.329 euros per capita (standard error, 3.303) for complying municipalities. This evidence is consistent with the institutional details discussed in Section I, according to which central transfers are used as the main enforcement device of the DSP. Consistent with the estimation results, tax revenues, ICI, and IRPEF show significant and negative jumps moving from just above to just below the 5,000 residents threshold.

\footnotetext{
${ }^{33}$ Specifically, if we repeat our RD estimations using compliance status as a dependent variable, we obtain the following results for the local linear regression and the spline polynomial approximation specifications, respectively: 0.450 (standard error, 0.070); 0.443 (0.054); 0.448 (0.076); 0.436 (0.096).
} 
Panel A

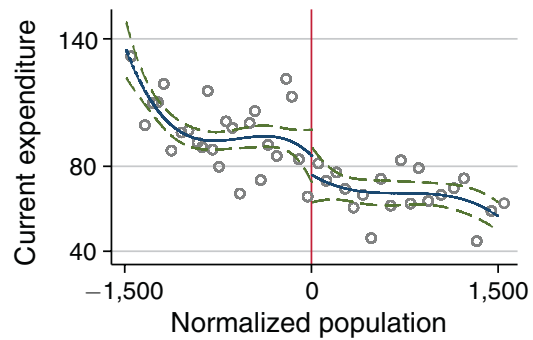

Panel C

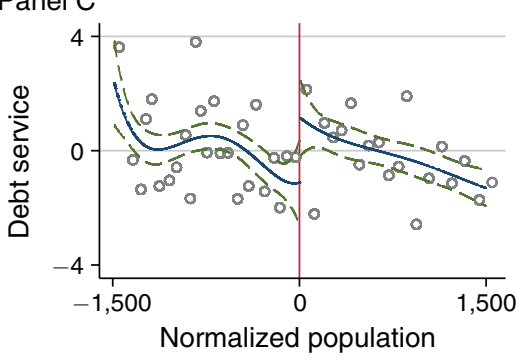

\section{Panel B}

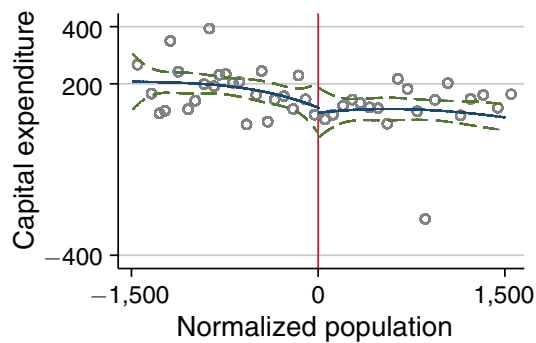

Figure 4. DifFERENCE-IN-Discontinuities FOR EXPENDITURES OUTCOMES

Notes: Difference-in-discontinuities. Vertical axis: difference of each post-rule (i.e., 2001, 2002, 2003, and 2004) outcome value and each pre-rule (i.e., 1999 and 2000) outcome value. Horizontal axis: actual population size minus 5,000 . The central line is a spline third-order polynomial fit; the lateral lines represent the 95 percent confidence interval. Scatter points are averaged over intervals of 50 inhabitants.

\section{B. Validity Tests}

As discussed in Section II, the above estimation results rest on Assumption 1 and Assumption 2 for the identification of different average treatment effects in the neighborhood of the population threshold. In this section, we indirectly evaluate Assumption 1 by means of testing procedures aimed at detecting changes in manipulative sorting before/after 2001, and we directly test Assumption 2 in a falsification test that uses pretreatment data.

In online Appendix Figure A2, we test the null hypothesis of continuity of the difference in the density at 5,000 between the 1991 and the 2001 census (top graph), by drawing both scatters and (third-order) polynomial fits. If mayors were able to manipulate population size and sort below the threshold to avoid fiscal rules, our estimates would still suffer from the selection bias that was common in the previous empirical literature. However, in principle, there is very little room for differential manipulation between the two censuses, because (i) the DSP is only enacted in December 2000; (ii) the census is run independently by the National Statistical Office, so that false reporting should be ruled out; and (iii) mayors willing to sort below 5,000 to enjoy a relaxation of fiscal rules would pay the price of cutting their wage. Nevertheless, it might still be the case that some municipalities under financial stress tried to sort below 5,000 moving from the 1991 to the 2001 census, by forcing some residents to leave or (more plausibly) not counter-reacting to population drops. Yet, the top graph in Figure A1 is reassuring about the absence of 


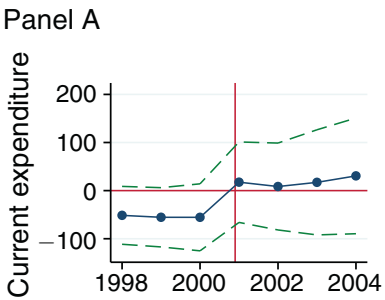

Panel D

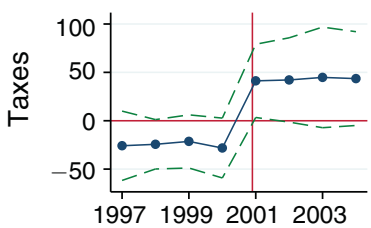

Panel G

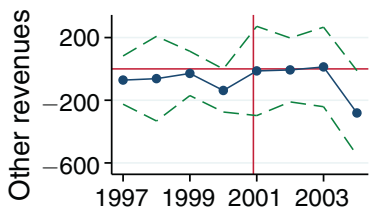

Panel B

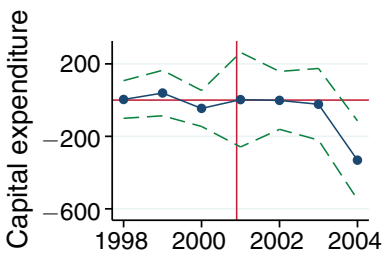

Panel E

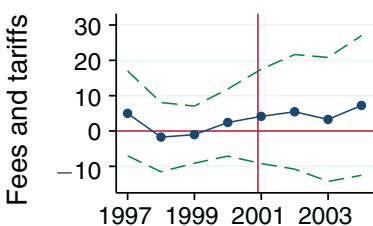

Panel $\mathrm{H}$

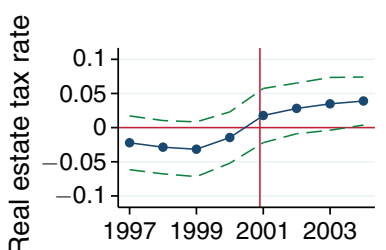

Panel C
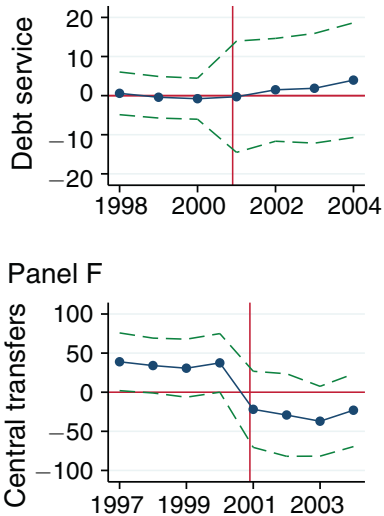

Panel I

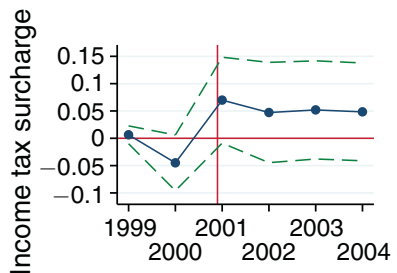

Figure 5. Yearly RD Estimates for Policy Outcomes and Tax Instruments

Notes: Yearly RD coefficients. Vertical axis: point estimates of local linear regressions with optimal bandwidth computed following Calonico, Cattaneo, and Titiunik (2014a, b). Horizontal axis: year. The central line is the point estimate; the lateral lines represent the 95 percent confidence interval.

manipulation, as there is no jump in the difference between the two densities. The point estimate from the spline polynomial approximation is equal to -0.078 (standard error, 0.114), and therefore is not statistically different from zero. For the sake of completeness, we also report the cross-sectional density tests for 1991 (bottom left) and 2001 (bottom right). Also there, there is no evidence of manipulation. ${ }^{34}$

Furthermore, in the online Appendix Table A3, we check for the balancing of time-invariant characteristics by including covariates, together with year fixed effects, in the baseline diff-in-disc estimations; as expected, point estimates remain almost unchanged and accuracy increases. The online Appendix Table A4 further evaluates the absence of manipulation. We implement diff-in-disc estimations with time-invariant characteristics (geographic location, area size, and sea level) as outcome variables, but we use changing population numbers: the 1991 census before the treatment year, and the 2001 census afterward. This is meant to assess whether the fraction of cities with certain fixed characteristics just below or above 5,000 varies from 1991 to 2001. No time-invariant characteristics display a statistically significant jump. We think that geographical location is a particularly interesting

\footnotetext{
${ }^{34}$ The 1991 point estimate is $0.068(0.082)$; the 2001 point estimate is $-0.010(0.076)$.
} 
dimension here because Italian geography is correlated with economic development, crime rates, and shirking (e.g., see Ichino and Maggi 2000; Nannicini et al. 2013; Casaburi and Troiano 2016), and it could thus be associated with opportunistic manipulation too.

Based on this large amount of supporting evidence on Assumption 1, in online Appendix Table A5, we directly test Assumption 2 under the maintained hypothesis that Assumption 1 holds. In particular, we check whether cities just below or just above the 5,000 threshold respond differently to fiscal rules. We use the introduction of the DSP in 1999 for all municipalities as an experiment to test for the absence of any differential response around 5,000. Specifically, we implement diff-in-disc estimations in the interval 1997-2000, using 1999-2000 as the posttreatment period and 1997-1998 as the pretreatment period. All outcome variables are balanced around the threshold before/after 1999, confirming the assumption that the DSP did not interact with the confounding wage discontinuity and did not bind differently across different sides of the population threshold. ${ }^{35}$

In online Appendix Figure A3, we test the sensitivity of the estimates to the bandwidth for the other budget items. Point estimates for tax revenues, tax rates, and central transfers show the larger sensitivity to the bandwidth choice.

We also perform a set of placebo tests to evaluate the possibility that our results arise from random chance rather than a causal relationship. In the online Appendix Figures A4 and A5, in the spirit of DellaVigna and La Ferrara (2010), we implement - respectively, for deficit and for fiscal gap — a set of diff-in-disc estimations at false population thresholds below and above 5,000 (namely, any point from 3,900 to 4,900 and from 5,100 to 6,100 in order to stay sufficiently away from the true policy threshold). At these false thresholds, we expect to find no systematic evidence of treatment effects similar to our baseline results. The two figures report the cumulative density function of these 2,000 placebo point estimates (using a specification with third-order spline polynomial). The intuition here is that we should not observe too many coefficients outside the interval from the positive and negative value of the coefficient estimated using the true threshold. Indeed, all of the placebo coefficients are below our estimated coefficients for both deficit and fiscal gap, and the cumulative density function of the normalized coefficients is much steeper around zero. Only 3 percent of the placebo coefficients for the deficit and 5.5 percent of the placebo coefficients for fiscal gap are larger from the true coefficient in absolute value, and all of them have a different (negative) sign with respect to the (true) baseline estimate. On the whole, these placebo tests provide strong support for the robustness of our main results on fiscal discipline.

In online Appendix Table A7, we show that the effects are qualitatively similar when we drop years 2001 and 2002 (the years where every municipality faced the restraint) from the estimation. Finally, we show in the online Appendix Table A8 that the results are qualitatively identical when dropping 1999 and 2000 (the years where no municipality faced a fiscal restraint) from the estimations. The results in

\footnotetext{
${ }^{35}$ The city of Romentino was an outlier due to a lucrative sale of land in 1998 and it was removed from the sample. Our results do not change with the inclusion of this city, with the exception of bigger standard errors for other revenues.
} 
the previous tables suggest that the exact formulation of the restraint is not driving our main results, and this is encouraging for the external validity of our estimates.

\section{Political Economy of Fiscal Adjustment}

In this section, we exploit our research design to shed light on the political economy of the deficit. Evaluating the differential response of different politicians and voters to an exogenous (albeit local) variation in fiscal rules can identify important determinants of politically motivated deficits, and it provides new evidence about the costs and benefits of fiscal restraints. We start by looking at three political factors. First, we consider whether mayors face a binding term limit or not, because mayors in their second term have no reelection incentives and no personal stake in the city's budget for the following years. Second, we consider the number of parties in the city council—which, hence, vote on the budget proposed by the mayor - to capture political fragmentation and potential common pool problems. Third, we consider the age profile of citizens in our municipalities. We finally relate our findings to models that formalize the trade-off between reduced flexibility of fiscal policy and increased discipline on politically motivated deficit. Specifically, we consider the speed of public good provision (the ratio between provided public goods and the promised public goods promised to the voters in the provisional budget).

The results are reported in Table 5, where we implement the baseline diff-in-disc estimations interacting our treatment with: (i) binding versus nonbinding term limit; (ii) the number of parties in the city council; (iii) the fraction of inhabitants belonging to the youngest cohort; and (iv) the speed of public good provision. For each heterogeneity exercise, we report the diff-in-disc estimates of the relevant interaction. We are aware that the causal interpretation of the relevant interaction rests on an additional conditional independence assumption. This is why we report a second interaction coefficient (with covariates) indicating whether this difference is robust to a specification including a full set of interactions with covariates at the municipality level (namely, the average taxable income; mayor's years of schooling; and whether the municipality is in the north of the country). If this test is also statistically significant, it means that the differential impact of relaxing fiscal rules across our heterogeneity dimensions is not driven by those observable confounding city characteristics. ${ }^{36}$

First, we focus on term limits, exploiting the fact that Italian mayors face a two-term limit. ${ }^{37}$ Theoretical models suggest that the expectation of a future election can affect policies because politicians who plan to run again for office must please the voters sufficiently often to merit reelection (Barro 1973, Banks and Sundaram 1998). We find that the fiscal (de)stabilization induced by the relaxation of the fiscal restraints is driven by mayors without a binding term limit, although this result

\footnotetext{
${ }^{36}$ As a final robustness check on our heterogeneity analysis, we repeat the falsification test in 1999 for all the above dimensions. Specifically, in online Appendix Table A6 we implement the above heterogeneity diff-in-disc estimations in the interval 1997-2000, using 1999-2000 as the posttreatment period and 1997-1998 as the pretreatment period. The fact that no effect and no difference are ever statistically significant means that municipalities around the threshold in different heterogeneity subsamples are not on differential trends before 2001. In other words, the DSP did not bind differently across those subsamples.

${ }^{37}$ It should be noted that: (i) municipalities do not vote at the same time, and (ii) the DSP was independent of local politics because it followed agreements between the European Union and its member countries.
} 
Table 5-Political Economy of Deficit Bias

\begin{tabular}{lcc}
\hline \hline & Without covariates & With covariates \\
\hline Treatment $\times$ term limit & -27.653 & -23.680 \\
Treatment & $(13.858)$ & $(13.862)$ \\
& 28.881 & -23.869 \\
Term limit (mean) & $(11.707)$ & $(67.936)$ \\
Treatment $\times$ number of parties & 0.441 & 0.441 \\
& 10.372 & 5.094 \\
Treatment & $(5.377)$ & $(2.807)$ \\
& -8.613 & -8.809 \\
Number of parties (mean) & $(14.922)$ & $(37.419)$ \\
Treatment $\times$ young cohort & 2.66 & 2.66 \\
& & -8.998 \\
Treatment & -8.275 & $(3.714)$ \\
& $(3.869)$ & 122.359 \\
Young cohort (mean) & 135.931 & $(77.036)$ \\
Treatment $\times$ public good & $(54.665)$ & 14.164 \\
Treatment & 14.164 & -2.587 \\
& -3.168 & $(1.385)$ \\
Public good (mean) & $(1.444)$ & 181.683 \\
$h$ & 264.986 & $(142.206)$ \\
Observations & $(114.755)$ & 78.120 \\
& 78.120 & 600 \\
\hline
\end{tabular}

Notes: Municipalities between 3,500 and 7,000 inhabitants; budget years between 1999 and 2004. Diff-in-disc estimates of the impact of relaxing fiscal rules on fiscal discipline below 5,000 after 2001 interacted with the relevant heterogeneity dimension (that is, dummy for binding term limit; number of parties in the city council; dummy for above-median percentage of young cohorts; dummy for above-median speed of public good provision). Estimation method: local linear regression with the optimal bandwidth $h$ estimated following Calonico, Cattaneo, and Titiunik (2014a, b). The with covariates specification evaluates whether the estimates are statistically different in the two subsamples also controlling for a full set of interactions between the above specifications and appropriate covariates, which are: average taxable income; mayor's years of schooling; and whether the municipality is in the North. All variables are per capita and in 2009 euros. Robust standard errors clustered at the municipality level are in parentheses.

becomes borderline insignificant in some specifications that control for covariates. As mayors without term limits face both stronger reelection concerns and a higher expected probability that they (or their party) will remain in power, the above result provides more support for models linking deficits to reelection incentives (see Aghion and Bolton 1990) or to politicians' pandering to voters (see Maskin and Tirole 2004), rather than models viewing deficits as a way to tie the hands of future governments with different political preferences (see Alesina and Tabellini 1990; Persson and Svensson 1989; Tabellini and Alesina 1990). Unfortunately, we are not able to provide further empirical evidence on strategic voting models because of the lack of a clear expected reelection probability outcome in our data. ${ }^{38} \mathrm{We}$ are

\footnotetext{
${ }^{38}$ See Pettersson-Lidbom (2001) for an empirical evaluation of strategic voting models.
} 
also not able to rule out alternative channels that can rationalize our result on term limits, such as the possibility that political experience per se has an effect on how mayors react to the relaxation of fiscal rules, though it is encouraging that some of the results survive to controlling for the mayor's characteristics. 39

Second, we focus on political fragmentation. Political fragmentation generally arises when several agents have an active role in the allocation of the budget, each with its own constituency to please, and each with some weight in the final decision. There are two key determinants that affect how much a policymaker internalizes the costs of the demanded share of the budget: the number of decision makers participating in the bargaining process and the institutional rules determining the aggregation of preferences. Most empirical studies focus on the first determinant because of a lack of reliable proxies for the rules that determine the budget allocation across countries. We also follow this previous literature by focusing on the first determinant. However, one advantage of our setting is that we can safely assume that the rules that determine the allocation of the budget are constant around our threshold. Our proxy for political fragmentation is the number of parties in the city councils. The majority of the municipalities in our sample have either one, or two, or three parties represented in the city council. Typically, there is at least one party in charge of the municipal government, and one party in the opposition. The estimation results reported in Table 5 show that the increase in deficit is stronger the higher is the number of parties in the city council. Our favorite interpretation of this result is that is consistent with models that explain fiscal instability in terms of political fragmentation or dynamic common pool (see Persson and Tabellini 2000). However, this may not be the only interpretation of how political fragmentation affects fiscal instability. For instance, other existing models predict a negative relationships between the number of parties and fiscal discipline (Pettersson-Lidbom 2012; Hargaden 2014). Because of the nature of our setting and our evidence, we do not aim at discriminating among the different models of how parties affect deficit.

Consistent with the model of Song, Storesletten, and Zilibotti (2012), the deficit increases after the relaxation of the rule in cities with a smaller proportion of young citizens. Song, Storesletten, and Zilibotti (2012) propose a dynamic politico-economic theory of fiscal policy for small open economies, and we view this model as particularly relevant for our setting because small cities are a reasonably good approximation of small open economies. The main intuition of their model is that younger citizens impose a disciplining effect on fiscal policy, because they internalize the future costs of a presently loose fiscal policy. Both of the above predictions are borne out by our empirical findings. 40

Finally, we check whether our treatment interacts with the speed of public good provision: the ratio between the public goods actually delivered and the public goods

\footnotetext{
${ }^{39}$ Given that we can control for the selection of mayors (years of schooling), our findings provide additional support to the literature that focuses on the effect of term limit on political accountability and in-office performance (see Besley and Case 1995; List and Sturm 2006).

${ }^{40}$ Another testable prediction of their model is that deficit should be higher for cities where the mayor is affiliated with right-wing parties. While most of the mayors in our sample are not affiliated with parties that can be clearly mapped to the ideological spectrum, we also find evidence that is consistent with this prediction in the (small) subset of mayors affiliated to a political party.
} 
promised to the voters in the budget. Our indicator of the speed of public good provision is calculated as a mayor-specific measure, averaged across all the years each mayor is in office. ${ }^{41}$ These results show that the increase in deficit arises only for mayors that systematically under-provide the public goods promised to voters in the provisional budget. This evidence could be interpreted as consistent with a potential negative effect for voters following the relaxation of the rule, only to the extent to which politicians who consistently over-promise public goods are those who care more about reelection rather than social welfare (Besley 2007). However, we can not rule out that mayors who are slower in providing public goods provide goods of better quality, and, hence, the previous result should be interpreted with caution.

All in all, the results discussed in this section suggest that fiscal restraints are more likely to bind for cities characterized by political failures.

\section{Conclusion}

Limiting the increase of public debt is a key policy issue in most economies. Fiscal rules are usually considered one of the potential solutions to public debt growth. In this paper, we rely on a novel quasi-experimental design to show that fiscal rules enforced by a national government can be effective in causing a reduction of the accumulation of debt by local governments. Additionally, we are able to investigate the composition of fiscal adjustment and we show that unconstrained cities have lower tax rates and lower revenues following the relaxation of fiscal rules. We then link our results to existing theories of fiscal adjustment to provide new evidence about the costs and benefits of restraining fiscal policy. We show that a deficit arises only where many parties are represented in the city council, mayors can run for reelection, there is a smaller proportion of young citizens, and mayors systematically underprovide the promised public good. These results suggest that fiscal restraints can be more effective when political distortions are larger.

We are aware that the enhanced internal validity of our evaluation design comes at the price of lower external validity, as is always the case in (local) econometric strategies based on policy discontinuities. However, we believe that the fact that the restraint worked in Italy, a country often cited for poor legal enforcement, could potentially offer a valuable lesson for other developed economies.

Our results raise a number of questions for further research. First, we show that fiscal rules, when accompanied by a proper enforcement mechanism, can be effective also in regulatory environments characterized by serious commitment issues such as the Italian case. Hence, fiscal rules might be useful in far more cases than those suggested by the conventional wisdom, and the optimal design of fiscal rules should take into account political incentives in the enforcement of the rules. Second, our results on the composition of fiscal adjustment suggest that stabilizing fiscal policy through revenues and through expenditures might not be politically equivalent, although the standard errors don't allow drawing a strong conclusion. With this last caveat in mind, in our setting, politicians seem to be more prone to raising taxes

\footnotetext{
${ }^{41}$ Rogoff (1990) argues that electoral incentives might distort fiscal policy because of the distorted incentives to over-provide public goods when it is more salient for voters.
} 
rather than cutting expenditures to comply with an exogenous incentive for fiscal stability. Alesina and Ardagna (2010) raise the point that expenditure reductions are usually more expansionary than tax increases, regardless of the existence of a fiscal rule. Future research could explore the hypothesis that fiscal rules targeting expenditures may improve welfare compared to rules targeting deficit. Third, little is known about the political incentives that drive the choice between cutting expenditures and raising taxes to achieve stabilization. A rapidly growing literature in public economics has shown how the salience of tax changes affects behavioral responses (see Chetty, Looney, and Kroft 2009). It is an exciting direction for future research to investigate whether public good provision is subject to similar issues, and whether policymakers can exploit voters' behavioral biases in their favor. ${ }^{42}$

Our last set of empirical results implies that political incentives drive local government responses to exogenously imposed fiscal restraints. Since restricting tax smoothing is the main welfare cost of fiscal restraints identified by the macroeconomic literature, and since mechanisms for smoothing business cycle fluctuations, such as unemployment insurance, are often administered at the national level (as discussed by Gavin and Perotti 1997 and Hines 2011), our results suggest that fiscal rules imposed on subnational governments might have limited welfare costs and significant benefits.

\section{REFERENCES}

Aghion, Philippe, Alberto Alesina, and Francesco Trebbi. 2004. "Endogenous Political Institutions." Quarterly Journal of Economics 119 (2): 565-611.

Aghion, Philippe, and Patrick Bolton. 1990. "Government domestic debt and the risk of default: A political-economic model of the strategic role of debt." In Public Debt Management: Theory and History, edited by Rudiger Dornbusch and Mario Draghi, 315-44. Cambridge: Cambridge University Press.

Alesina, Alberto, and Silvia Ardagna. 2010. "Large Changes in Fiscal Policy: Taxes versus Spending." In NBER Book Series Tax Policy and the Economy, Vol. 24, edited by Jeffrey R. Brown, 35-68. Chicago: University of Chicago Press.

Alesina, Alberto, and Tamim Bayoumi. 1996. "The Costs and Benefits of Fiscal Rules: Evidence from U.S. States.” National Bureau of Economic Research (NBER) Working Paper 5614.

Alesina, Alberto, and Roberto Perotti. 1996. "Fiscal Discipline and the Budget Process." American Economic Review 86 (2): 401-07.

Alesina, Alberto, and Roberto Perotti. 1999. "Budget Deficits and Budget Institutions." In Fiscal Institutions and Fiscal Performance, edited by James M. Poterba and Juergen von Hagen, 13-36. Chicago: University of Chicago Press.

-Alesina, Alberto, and Guido Tabellini. 1990. "A Positive Theory of Fiscal Deficits and Government Debt." Review of Economic Studies 57 (3): 403-14.

Alt, James E., and Robert C. Lowry. 1994. "Divided Government, Fiscal Institutions, and Budget Deficits: Evidence from the States.” American Political Science Review 88 (4): 811-28.

-Auerbach, Alan J. 2006. "Budget windows, sunsets, and fiscal control." Journal of Public Economics 90 (1): 87-100.

Azzimonti, Marina, Marco Battaglini, and Stephen Coate. 2010. "On the Case for a Balanced Budget Amendment to the U.S. Constitution.” Munich Personal RePEc Archive (MPRA) Paper 25935.

Balassone, Fabrizio, Daniele Franco, and Stefania Zotteri. 2004. "Fiscal Rules for Subnational Governments: Lessons from the EMU." In Rules-Based Fiscal Policy in Emerging Markets: Background, Analysis and Prospects, edited by Geroge Kopits, 219-34. London: Palgrave Macmillan.

- Bandiera, Oriana, Andrea Prat, and Tommaso Valletti. 2009. "Active and Passive Waste in Government Spending: Evidence from a Policy Experiment.” American Economic Review 99 (4): 1278-1308.

${ }^{42} \mathrm{~A}$ first attempt along these lines is represented by Bisin, Lizzeri, and Yariv (2014). 
- Banks, Jeffrey S., and Rangarajan K. Sundaram. 1998. "Optimal Retention in Agency Problems." Journal of Economic Theory 82 (2): 293-323.

Barro, Robert J. 1973. "The Control of Politicians: An Economic Model." Public Choice 14 (1): $19-42$.

- Barro, Robert J. 1974. “Are Government Bonds Net Wealth?” Journal of Political Economy 82 (6): 1095-1117.

-Barro, Robert J. 1979. "On the Determination of the Public Debt." Journal of Political Economy 87 (5, Pt. 1): 940-71.

Bassetto, Marco, and Thomas J. Sargent. 2006. "Politics and Efficiency of Separating Capital and Ordinary Government Budgets.” Quarterly Journal of Economics 121 (4): 1167-1210.

- Battaglini, Marco, and Stephen Coate. 2008. "A Dynamic Theory of Public Spending, Taxation, and Debt." American Economic Review 98 (1): 201-36.

Bayoumi, Tamim, and Barry Eichengreen. 1995. "Restraining Yourself: The Implications of Fiscal Rules for Economic Stabilization.” IMF Staff Papers 42 (1): 32-48.

Besley, Timothy. 2007. Principled Agents? The Political Economy of Good Government. Oxford: Oxford University Press.

- Besley, Timothy, and Anne Case. 1995. "Does Electoral Accountability Affect Economic Policy Choices? Evidence from Gubernatorial Term Limits." Quarterly Journal of Economics 110 (3): 769-98.

- Besley, Timothy, and Michael Smart. 2007. "Fiscal restraints and voter welfare." Journal of Public Economics 91 (3): 755-73.

Bisin, Alberto, Alessandro Lizzeri, and Leeat Yariv. 2014. "Government Policy with Time Inconsistent Voters.” http://www.nyu.edu/econ/user/bisina/BisinLizzeriYarivRev1_05-14-14.pdf.

Bohn, Henning, and Robert P. Inman. 1996. "Balanced-budget rules and public deficits: Evidence from the U.S. states." In Carnegie-Rochester Conference Series on Public Policy, Vol. 45, edited by A. H. Meltzer and C. I. Plosser, 13-76. Amsterdam: North-Holland.

Bordignon, Massimo, Tommaso Nannicini, and Guido Tabellini. 2013. "Moderating Political Extremism: Single Round vs. Runoff Elections under Plurality Rule." Institute for the Study of Labor (IZA) Discussion Paper 7561.

Braun, Miguel, and Mariano Tommasi. 2004. "Subnational Fiscal Rules: A Game Theoretic Approach." In Rules-Based Fiscal Policy in Emerging Markets, edited by Geroge Kopits, 183-97. London: Palgrave Macmillan.

Calonico, Sebastian, Matias D. Cattaneo, and Rocio Titiunik. 2014a. "Robust data-driven inference in the regression-discontinuity design.” Stata Journal 14 (4): 909-46.

- Calonico, Sebastian, Matias D. Cattaneo, and Rocio Titiunik. 2014b. "Robust Nonparametric Confidence Intervals for Regression-Discontinuity Designs.” Econometrica 82 (6): 2295-2326.

Calzolari, Giacomo, Andrea Ichino, Francesco Manaresi, and Viki Nellas. 2014. "When the Baby Cries at Night: Inelastic Buyers in Non-Competitive Markets." Institute for the Study of Labor (IZA) Discussion Paper 8490.

Campa, Pamela. 2011. "Gender Quotas, Female Politicians and Public Expenditures: QuasiExperimental Evidence.” http://unicreditanduniversities.eu/uploads/assets/UWIN/CAMPA_ PAPER.pdf.

Casaburi, Lorenzo, and Ugo Troiano. 2016. "Ghost-House Busters: The Electoral Response to a Large Anti-Tax Evasion Program.” Quarterly Journal of Economics 131 (1): 273-314.

-Casas-Arce, Pablo, and Albert Saiz. 2015. "Women and Power: Unpopular, Unwilling, or Held Back?" Journal of Political Economy 123 (3): 641-69.

-Cellini, Stephanie Riegg, Fernando Ferreira, and Jesse Rothstein. 2010. "The value of school facility investments: Evidence from a dynamic regression discontinuity design." Quarterly Journal of Economics 125 (1): 215-61.

-Chetty, Raj, Adam Looney, and Kory Kroft. 2009. "Salience and Taxation: Theory and Evidence." American Economic Review 99 (4): 1145-77.

Clemens, Jeffrey P. 2012. "State Fiscal Adjustment during Times of Stress: Possible Causes of the Severity and Composition of Budget Cuts." Unpublished.

-Clemens, Jeffrey, and Stephen Miran. 2012. "Fiscal Policy Multipliers on Subnational Government Spending." American Economic Journal: Economic Policy 4 (2): 46-68.

Debrun, Xavier, Laurent Moulin, Alessandro Turrini, Joaquim Ayuso-i-Casals, and Manmohan S. Kumar. 2008. "Tied to the Mast? National Fiscal Rules in the European Union." Economic Policy 23 (54): 297-362.

-DellaVigna, Stefano, and Eliana La Ferrara. 2010. "Detecting Illegal Arms Trade." American Economic Journal: Economic Policy 2 (4): 26-57. 
Dickert-Conlin, Stacy, and Todd Elder. 2010. "Suburban legend: School cutoff dates and the timing of births." Economics of Education Review 29 (5): 826-41.

Drazen, Allan. 2002. "Fiscal rules from a political economy perspective." Paper presented at the IMFWorld Bank Conference on Rules-Based Fiscal Policy in Emerging Market Economies, Oaxaca, Mexico, February 14-16.

Eichengreen, Barry, and Jurgen Von Hagen. 1996. "Fiscal Policy and Monetary Union: Is There a Tradeoff between Federalism and Budgetary Restrictions?" National Bureau of Economic Research (NBER) Working Paper 5517.

Feld, Lars P., and Gebhard Kirchgässner. 2008. "On the Effectiveness of Debt Brakes: The Swiss Experience." In Sustainability of Public Debt, edited by Reinhard Neck and Jan-Egbert Sturm, 223-55. Cambridge: MIT Press.

-Gagliarducci, Stefano, and Tommaso Nannicini. 2013. "Do Better Paid Politicians Perform Better? Disentangling Incentives from Selection." Journal of the European Economic Association 11 (2): 369-98.

Gavin, Michael, and Roberto Perotti. 1997. "Fiscal Policy in Latin America." In NBER Macroeconomics Annual 1997, Vol. 12, edited by Ben S. Bernanke and Julio J. Rotemberg, 11-72. Cambridge: MIT Press.

Gelman, Andrew, and Guido Imbens. 2014. "Why High-Order Polynomials Should Not Be Used in Regression Discontinuity Designs.” National Bureau of Economic Research (NBER) Working Paper 20405.

-Givati, Yehonatan, and Ugo Troiano. 2012. "Law, Economics, and Culture: Theory of Mandated Benefits and Evidence from Maternity Leave Policies." Journal of Law and Economics 55 (2): 339-64.

Glaeser, Edward L. 2013. “Urban Public Finance.” In Handbook of Public Economics, Vol. 5, edited by Alan J. Auerbach, Raj Chetty, Martin Feldstein, and Emmanuel Saez, 195-256. Amsterdam: North-Holland.

Grembi, Veronica, Tommaso Nannicini, and Ugo Troiano. 2012. "Policy Responses to Fiscal Restraints: A Difference-in-Discontinuities Design." Institute for the Study of Labor (IZA) Discussion Paper 6952.

Grembi, Veronica, Tommaso Nannicini, and Ugo Troiano. 2016. "Do Fiscal Rules Matter?: Dataset." American Economic Journal: Applied Economics. http://dx.doi.org/10.1257/app.20150076.

-Hahn, Jinyong, Petra Todd, and Wilbert Van der Klaauw. 2001. "Identification and Estimation of Treatment Effects with a Regression-Discontinuity Design." Econometrica 69 (1): 201-09.

Hallerberg, Mark, and Juergen von Hagen. 1999. "Electoral Institutions, Cabinet Negotiations, and Budget Deficits in the European Union." In Fiscal Institutions and Fiscal Performance, edited by Juergen von Hagen and James Poterba, 209-32. Chicago: University of Chicago Press.

Hargaden, Enda Patrick. 2014. "Political Fragmentation and Fiscal Policy." http://www.hargaden. com/enda/hargaden_fragmentation.pdf.

-Hines, James R., Jr., William G. Gale, and Brian Knight. 2010. "State Fiscal Policies and Transitory Income Fluctuations.” Brookings Papers on Economic Activity 2010 (2): 313-50.

- Ichino, Andrea, and Giovanni Maggi. 2000. "Work Environment and Individual Background: Explaining Regional Shirking Differentials in a Large Italian Firm." Quarterly Journal of Economics 115 (3): 1057-90.

Imbens, Guido W., and Thomas Lemieux. 2008. "Regression discontinuity designs: A guide to practice." Journal of Econometrics 142 (2): 615-35.

International Monetary Fund. 2009. Fiscal Rules: Anchoring Expectations for Sustainable Public Finances. Fiscal Affairs Department. Washington, DC, December.

Kaufmann, Daniel, Aart Kraay, and Massimo Mastruzzi. 2010. "The Worldwide Governance Indicators: Methodology and Analytical Issues." World Bank Policy Research Working Paper 5430.

-Knight, Brian G. 2000. "Supermajority voting requirements for tax increases: Evidence from the states." Journal of Public Economics 76 (1): 41-67.

Lalive, Rafael. 2008. "How do extended benefits affect unemployment duration? A regression discontinuity approach." Journal of Econometrics 142 (2): 785-806.

Lee, David S., and Thomas Lemieux. 2010. "Regression Discontinuity Designs in Economics." Journal of Economic Literature 48 (2): 281-355.

Lemieux, Thomas, and Kevin Milligan. 2008. "Incentive effects of social assistance: A regression discontinuity approach." Journal of Econometrics 142 (2): 807-28.

Leonardi, Marco, and Giovanni Pica. 2013. "Who Pays For It? The Heterogeneous Wage Effects of Employment Protection Legislation.” Economic Journal 123 (573): 1236-78.

List, John A., and Daniel M. Sturm. 2006. "How Elections Matter: Theory and Evidence from Environmental Policy.” Quarterly Journal of Economics 121 (4): 1249-81. 
-Lizzeri, Alessandro. 1999. "Budget Deficits and Redistributive Politics." Review of Economic Studies 66 (4): 909-28.

Lucas, Robert E., Jr., and Nancy L. Stokey. 1983. "Optimal fiscal and monetary policy in an economy without capital." Journal of Monetary Economics 12 (1): 55-93.

- Ludwig, Jens, and Douglas L. Miller. 2007. "Does Head Start Improve Children's Life Chances? Evidence from a Regression Discontinuity Design." Quarterly Journal of Economics 122 (1): 159-208.

- Maskin, Eric, and Jean Tirole. 2004. "The Politician and the Judge: Accountability in Government." American Economic Review 94 (4): 1034-54.

McCrary, Justin. 2008. "Manipulation of the running variable in the regression discontinuity design: A density test." Journal of Econometrics 142 (2): 698-714.

- Milesi-Ferretti, Gian Maria. 2004. "Good, bad or ugly? On the effects of fiscal rules with creative accounting." Journal of Public Economics 88 (1): 377-94.

Nannicini, Tommaso, Andrea Stella, Guido Tabellini, and Ugo Troiano. 2013. "Social Capital and Political Accountability." American Economic Journal: Economic Policy 5 (2): 222-50.

- Persson, Torsten, and Lars E. O. Svensson. 1989. "Why a Stubborn Conservative Would Run a Deficit: Policy with Time-Inconsistent Preferences." Quarterly Journal of Economics 104 (2): 325-45.

Persson, Torsten, and Guido Tabellini. 2000. Political Economics: Explaining Economic Policy. Cambridge: MIT Press.

-Pettersson-Lidbom, Per. 2001. "An Empirical Investigation of the Strategic Use of Debt." Journal of Political Economy 109 (3): 570-83.

Pettersson-Lidbom, Per. 2012. "Does the size of the legislature affect the size of government? Evidence from two natural experiments." Journal of Public Economics 96 (3): 269-78.

Poterba, James M. 1994. "State Responses to Fiscal Crises: The Effects of Budgetary Institutions and Politics." Journal of Political Economy 102 (4): 799-821.

Poterba, James M. 1996. "Budget Institutions and Fiscal Policy in the U.S. States." American Economic Review 86 (2): 395-400.

Poterba, James M., and Jürgen von Hagen. 1999. Fiscal Institutions and Fiscal Performance. Chicago: University of Chicago Press.

Rogoff, Kenneth. 1990. "Equilibrium Political Budget Cycles." American Economic Review 80 (1): 21-36.

-Song, Zheng, Kjetil Storesletten, and Fabrizio Zilibotti. 2012. "Rotten Parents and Disciplined Children: A Politico-Economic Theory of Public Expenditure and Debt." Econometrica 80 (6): 2785-2803.

Sutherland, Douglas, Robert Price, and Isabelle Joumard. 2005. "Fiscal rules for sub-central governments: Design and impact." Organisation of Economic Co-operation and Development (OECD) Economics Department Working Paper 465.

Tabellini, Guido, and Alberto Alesina. 1990. "Voting on the budget deficit." American Economic Review 80 (1): 37-49.

- Ter-Minassian, Teresa. 2007. "Fiscal Rules for Subnational Governments: Can They Promote Fiscal Discipline?" OECD Journal on Budgeting 6 (3): 1-11.

Van der Klaauw, Wilbert. 2008. "Regression-Discontinuity Analysis: A Survey of Recent Developments in Economics." Labour 22 (2): 219-45.

-Von Hagen, Jürgen. 1991. "A note on the empirical effectiveness of formal fiscal restraints." Journal of Public Economics 44 (2): 199-210.

Wyplosz, Charles. 2012. "Fiscal rules: Theoretical issues and historical experiences." National Bureau of Economic Research (NBER) Working Paper 17884.

-Yared, Pierre. 2010. "Politicians, Taxes and Debt." Review of Economic Studies 77 (2): 806-40. 
This article has been cited by:

1. Decio Coviello, Stefano Gagliarducci. 2017. Tenure in Office and Public Procurement. American Economic Journal: Economic Policy 9:3, 59-105. [Abstract] [View PDF article] [PDF with links]

2. Brian Beach, Daniel B. Jones. 2017. Gridlock: Ethnic Diversity in Government and the Provision of Public Goods. American Economic Journal: Economic Policy 9:1, 112-136. [Abstract] [View $\mathrm{PDF}$ article] [PDF with links] 